\title{
Synthesis of $\mathrm{SO}_{4}{ }^{2-} / \mathrm{ZrO}_{2}$ Solid Acid and $\mathrm{Na}_{2} \mathrm{O} / \mathrm{ZrO}_{2}$ Solid Base Catalysts Using Hydrothermal Method for Biodiesel Production from Low-Grade Crude Palm Oil
}

\author{
Sri Setyaningsih ${ }^{1}$, Maisari Utami ${ }^{2}$, Akhmad Syoufian $^{3}$, Eddy Heraldy ${ }^{4}$, \\ Nasih Widya Yuwono ${ }^{5}$, and Karna Wijaya ${ }^{3^{*}}$
}

${ }^{1}$ Department of Science Education, Faculty of Teacher Training and Education, Universitas Islam Lamongan, Jl. Veteran No. 53A, Lamongan 62211, Indonesia

${ }^{2}$ Department of Chemistry, Faculty of Mathematics and Natural Sciences, Universitas Islam Indonesia, Jl. Kaliurang km. 14, Yogyakarta 55584, Indonesia

${ }^{3}$ Department of Chemistry, Faculty Mathematics and Natural Science, Universitas Gadjah Mada, Sekip Utara, PO BOX BLS 21, Yogyakarta 55281, Indonesia

${ }^{4}$ Department of Chemistry, Faculty of Mathematics and Natural Sciences, Sebelas Maret University, Jl. Ir. Sutami 36A, Surakarta 57126, Central Java, Indonesia

${ }^{5}$ Department of Soil Science, Faculty of Agriculture, Universitas Gadjah Mada, Jl. Flora, Bulaksumur, Yogyakarta 55281, Indonesia

\section{* Corresponding author:}

email:karnawijaya@ugm.ac.id

Received: April 20, 2021

Accepted: October 18, 2021

DOI: $10.22146 / \mathrm{ijc} .65404$

\begin{abstract}
Biodiesel is a renewable energy source that can be produced through esterification as well as transesterification reactions. This work presents a series of zirconia catalysts synthesized by hydrothermal method on various concentrations in acidic $\left(\mathrm{H}_{2} \mathrm{SO}_{4} 0.3,0.5\right.$, and $\left.0.7 \mathrm{M}\right)$ and basic $(\mathrm{NaOH} \mathrm{1,2,3}$, and $4 \mathrm{M})$ solution to get a catalyst with the highest acidity or basicity. Characterizations of the catalysts were performed by FTIR, XRD, SEM-EDX, surface area analysis, acidity, and basicity test. The most active acid catalyst activity was evaluated for the esterification of low-grade crude palm oil (LGCPO), while the solid base catalyst was utilized for the transesterification reaction. The solid acid catalyst of $0.7 \mathrm{M} \mathrm{SO}_{4}{ }^{2-} / \mathrm{ZrO}_{2} 60^{\circ} \mathrm{C} ; 24 \mathrm{~h}$ was denoted as the most active acid catalyst with a total acidity of $1.86 \mathrm{mmol} \mathrm{g}$, while $4 \mathrm{M} \mathrm{Na}_{2} \mathrm{O} / \mathrm{ZrO}_{2} 60^{\circ} \mathrm{C} ; 24 \mathrm{~h}$ catalyst was considered as the solid base catalyst with the highest total basicity of $3.75 \pm$ $0.12 \mathrm{mmol} \mathrm{g}^{-1}$. The optimized acid catalyst exhibited a 31 times higher acidity than commercial $\mathrm{ZrO}_{2}$. The concentration of free fatty acids (FFA) decreased to $68.87 \%$ in the esterification reaction. The solid base catalyst of $4 \mathrm{M} \mathrm{Na}_{2} \mathrm{O} / \mathrm{ZrO}_{2} 60^{\circ} \mathrm{C} ; 24 \mathrm{~h}$ successfully converted LGCPO into biodiesel by $68.55 \%$ through a transesterification reaction.
\end{abstract}

Keywords: $\mathrm{SO}_{4}{ }^{2-} / \mathrm{ZrO}_{2}$ solid acid catalyst; $\mathrm{Na}_{2} \mathrm{O} / \mathrm{ZrO}_{2}$ solid base catalyst; esterification; transesterification; biodiesel

\section{- INTRODUCTION}

More than $90 \%$ of the consumption of energy sources in the world is currently based on fossil fuels [1]. Fossil fuels are a limited source of energy. One effort to tackle the scarcity of fossil fuels is creating alternative fuels. Biodiesel is a monoalkyl ester compound that has the potential to be an alternative renewable fuel. Biodiesel has been widely accepted in the market because of its low sulfur content and higher octane number than petrodiesel [1]. The presence of $11-15 \%$ oxygen in biodiesel can accelerate the combustion process and reduce the number of particulates, soot, and $\mathrm{CO}$ gas. Therefore, greenhouse gas emissions are low [2-3].

Biodiesel is formed from the conversion of free fatty acids and triglycerides to methyl esters. The source of triglycerides (TG) and free fatty acids (FFA) are 
generally contained in vegetable and animal oils [4]. Low Grade Crude Palm Oil (LGCPO) produced by the oil industry as a waste containing triglycerides and FFA can be used as raw material for forming methyl esters [5]. LGCPO has been used as raw material for low grade soap and boiler fuel. Therefore, processing LGCPO into biodiesel can increase its value. LGCPO raw materials are high abundance and inexpensive, so they have the potential to be developed on a large scale with low production costs [6].

In general, biodiesel is produced through a transesterification reaction by adding a base catalyst when the FFA number in the raw material is $<2 \mathrm{wt} . \%$. Highly FFA will affect the formation of biodiesel. The concentration of FFA exceeds more than 1\%, causing saponification when catalyzed using base catalysts such as $\mathrm{NaOH}$ [7]. The soap formation will complicate the separation process and cause a low yield. A two-step process through esterification reaction using an acid catalyst followed by transesterification using a base catalyst is employed to overcome this problem [8]. The acid catalyst is needed to reduce the concentration of FFA in the raw material by the esterification reaction [9]. Esterification is a reversible reaction that aims to reduce the concentration of FFA using an acid catalyst, where one mole of FFA will react with one mole of alcohol to form one mole of biodiesel and one mole of water [10-11].

Most methyl ester formation reactions are catalyzed by homogeneous base catalysts such as $\mathrm{NaOH}$ and $\mathrm{KOH}$ $[1,8]$. However, the application of homogeneous catalysts causes the separation process to be complicated, reactor corrosion, and an increasing amount of pollutants [12]. On the other hand, heterogeneous catalysts have advantages such as being easily separated and having low pollutants $[8,13]$. Therefore, the method of heterogeneous catalyst synthesis that is safe for the environment with low production costs is being developed [4]. The ideal characteristic of heterogeneous catalysts is a strong acid or base site, hydrophobic surface area, large pores interconnected, high activity, selective, stable to pressure and temperature [14-15]. For example, zirconia dioxide $\left(\mathrm{ZrO}_{2}\right)$ can be used as a catalyst and supporting material because it has redox activity and bifunctionality for both acidity and basicity properties [16-17]. Research using heterogeneous acid and base catalysts from $\mathrm{ZrO}_{2}$ to produce biodiesel has evolved today [18-19].

Sulfated zirconia as a catalyst has been successfully synthesized using the sol-gel method, precipitation, and wet impregnation. The weakness of the sol-gel method is the difficulties of the preparation process on $\mathrm{pH}$ control, composition, and temperature that affect the synthesized material. In addition, the precursors are expensive. The route of material synthesis using the precipitation method is easier, but the shape of the particles is irregular, and the size distribution is wide. The material synthesized using the hydrothermal method has a lower crystallization temperature and agglomeration rate. The resulted powder is good without calcination. The shape and distribution of particle size are controlled [20]. However, no previous publication has developed a hydrothermal method to investigate the activity of monoclinic zirconia as an acid and base catalyst.

Sulfated zirconia $\left(\mathrm{SO}_{4}{ }^{2-} / \mathrm{ZrO}_{2}\right)$ has been reported to have super acidic properties [21]. The strong acid character is caused by the presence of sulfate ions which bind to the substrate [22]. Its high acid strength and combination of acid sites (Brønsted and Lewis) are the most significant factors in enhancing selectivity and activity [11]. The superiority of this catalyst is its high activity at relatively low temperatures [23]. $\mathrm{SO}_{4}{ }^{2-} / \mathrm{ZrO}_{2}$ has a catalytic activity that can convert hydrocarbons at low temperatures [24]. The lack of $\mathrm{SO}_{4}{ }^{2-} / \mathrm{ZrO}_{2}$ catalysts are the limited surface area that affects the acidity, so some modifications are developed to increase the acidity of the catalyst. The physical and chemical properties of this catalyst are determined by the sulfation method [25]. Synthesis in hydrothermal conditions offers significant advantages, such as easily controlling particle size and morphology by optimizing synthesis parameters and conditions [26]. Catalytic activities of $\mathrm{SO}_{4}{ }^{2-} / \mathrm{ZrO}_{2}$ can be improved by optimizing the preparation conditions to enhance the zirconia framework's acidic strength [27].

The catalytic activity of $\mathrm{ZrO}_{2}$ in the transesterification reaction is not great because of its 
weak basic properties. On the other hand, the existence of empty sites on the surface of $\mathrm{ZrO}_{2}$ facilitates molecular dispersion to be used as an excellent supporting material [28]. The prospect of supporting basic species on metal oxide supports is expected to tune the basicity and redox properties, leading to a more active and selective catalytic system [29]. The common method used to increase the basic strength of the catalyst is by modifying a supporting material using alkali and alkaline earth metals [30]. It is well-known that alkali metals (such as $\mathrm{Li}, \mathrm{Na}$, and $\mathrm{K}$ ) or alkaline earth have good interactions for transesterification reactions and can be applied to supporting materials such as bentonite, $\mathrm{Al}_{2} \mathrm{O}_{3}, \mathrm{SiO}_{2}$, and activated carbon. The metals loading on a supporting material produces heterogeneous catalysts that can increase the transesterification reaction's activity [31]. Modifying the $\mathrm{ZrO}_{2}$ matrix with $\mathrm{NaOH}$ to synthesize heterogeneous base catalysts with high catalytic activity becomes challenging to develop.

Catalyst synthesis using the hydrothermal method is expected to increase the dispersion of $\mathrm{SO}_{4}{ }^{2-}$ or $\mathrm{Na}^{+}$in the $\mathrm{ZrO}_{2}$ matrix and strengthen the acidity or basicity of the catalyst. This research led to synthesizing $\mathrm{SO}_{4}{ }^{2-} / \mathrm{ZrO}_{2}$ solid acid and $\mathrm{Na}_{2} \mathrm{O} / \mathrm{ZrO}_{2}$ solid base catalyst by hydrothermal method for converting LGCPO to biodiesel. The method is highlighted to enhance the catalytic performance of both catalysts by providing more acid and base sites for the potential applications of biodiesel production. The solid catalysts and the catalytic activities of the obtained product are optimized to obtain the best results.

\section{- EXPERIMENTAL SECTION}

\section{Materials}

Commercial zirconium dioxide $\left(\mathrm{ZrO}_{2}\right)$ was acquired from Jiaozou Huasu Chemical Co., Ltd (Henan, China). LGCPO was obtained from one of the palm oil factories in Kabupaten Lampung Selatan, Lampung, Indonesia. The analytical reagents were sulfuric acid $\left(\mathrm{H}_{2} \mathrm{SO}_{4} 98 \%\right)$, sodium hydroxide $(\mathrm{NaOH})$, ammonium hydroxide $\left(\mathrm{NH}_{4} \mathrm{OH} 25 \%\right)$, methanol $\left(\mathrm{CH}_{3} \mathrm{OH}\right)$, hydrochloric acid $(\mathrm{HCl})$, potassium hydroxide $(\mathrm{KOH})$, sodium sulfate anhydrous $\left(\mathrm{Na}_{2} \mathrm{SO}_{4}\right)$, oxalic acid $\left(\mathrm{C}_{2} \mathrm{H}_{2} \mathrm{O}_{4}\right)$ and phenolphthalein indicators purchased from Merck.

\section{Instrumentation}

The catalysts were characterized using Fourier Transform Infrared Spectrophotometer (FTIR, Shimadzu Prestige-21), Scanning Electron Microscope (SEM, JEOL JSM-6510) combined with Energy Dispersive XRay (EDS, JED-2300 Analysis Station) and Surface Area Analyzer (SAA, Quadrasorb EVO Model QDS-30). The transesterification products were analyzed using Gas Chromatography-Mass Spectrometer (GC-MS, Shimadzu QP2010S), Fourier Transform Infrared Spectrophotometer (FTIR, Shimadzu Prestige-21), and Proton Nuclear Magnetic Resonance Spectrometer $\left({ }^{1} \mathrm{H}-\right.$ NMR, NMR JEOL NMR $500 \mathrm{MHz}$ ).

\section{Procedure}

\section{Synthesis of $\mathrm{SO}_{4}{ }^{2-} / \mathrm{ZrO}_{2}$ solid acid and $\mathrm{Na}_{2} \mathrm{O} / \mathrm{ZrO}_{2}$ solid base catalysts}

The $\mathrm{SO}_{4}{ }^{2-} / \mathrm{ZrO}_{2}$ catalysts were synthesized from $5 \mathrm{~g}$ of $\mathrm{ZrO}_{2}$ and $75 \mathrm{~mL}$ of $\mathrm{H}_{2} \mathrm{SO}_{4}$ with various concentrations of $0.3,0.5$, and $0.7 \mathrm{M}$ using the hydrothermal method. After being mixed perfectly, it was put into an autoclave and heated at a temperature of $60^{\circ} \mathrm{C}$ for $24 \mathrm{~h}$. The solid mixture and solution were separated by centrifugation at $2500 \mathrm{rpm}$ for $15 \mathrm{~min}$. Finally, the separate solids were heated at a temperature of $105^{\circ} \mathrm{C}$ for $24 \mathrm{~h} \mathrm{[32].} \mathrm{Catalysts}$ that have been synthesized were labeled as $0.3 \mathrm{M} \mathrm{SO}_{4}{ }^{2-}$ $/ \mathrm{ZrO}_{2} 60^{\circ} \mathrm{C} ; 24 \mathrm{~h}, 0.5 \mathrm{M} \mathrm{SO}_{4}{ }^{2-} / \mathrm{ZrO}_{2} 60^{\circ} \mathrm{C} ; 24 \mathrm{~h}$, and 0.7 $\mathrm{M} \mathrm{SO}_{4}{ }^{2-} / \mathrm{ZrO}_{2} 60{ }^{\circ} \mathrm{C} ; 24 \mathrm{~h}$. The catalysts were then characterized using FTIR and acidity tests.

The $\mathrm{Na}_{2} \mathrm{O} / \mathrm{ZrO}_{2}$ catalysts were synthesized by a similar method using $\mathrm{NaOH} 1,2,3$, and $4 \mathrm{M}$. The mixture was then heated at a temperature of $60^{\circ} \mathrm{C}$ for $12 \mathrm{~h}$ in an autoclave. The catalysts were denoted as $1 \mathrm{M} \mathrm{Na}_{2} \mathrm{O} / \mathrm{ZrO}_{2}$ $60{ }^{\circ} \mathrm{C} ; 12 \mathrm{~h}, 2 \mathrm{M} \mathrm{Na}_{2} \mathrm{O} / \mathrm{ZrO}_{2} 60^{\circ} \mathrm{C} ; 12 \mathrm{~h}, 3 \mathrm{M} \mathrm{Na}_{2} \mathrm{O} / \mathrm{ZrO}_{2}$ $60{ }^{\circ} \mathrm{C} ; 12 \mathrm{~h}$, and $4 \mathrm{M} \mathrm{Na}_{2} \mathrm{O} / \mathrm{ZrO}_{2} 60^{\circ} \mathrm{C} ; 12 \mathrm{~h}$ then characterized using FTIR and basicity test.

\section{Characterization of $\mathrm{SO}_{4}{ }^{2-} / \mathrm{ZrO}_{2}$ solid acid and $\mathrm{Na}_{2} \mathrm{O} / \mathrm{ZrO}_{2}$ solid base catalysts}

Each catalyst was characterized using Fourier Transform Infrared Spectrophotometer (FTIR, Shimadzu Prestige-21). Catalyst powder was diluted to an appropriate concentration of dry $\mathrm{KBr}$ with a ratio of 1:10 (catalyst:KBr) and pressed into a pellet using a 
compressor. The infrared spectrum was collected at $400-$ $4000 \mathrm{~cm}^{-1}$.

The acidity test of the acid catalyst was carried out using the gravimetric method. First, the empty crucible was weighed as $\mathrm{W}_{0}$. Next, a sample of $0.1 \mathrm{~g}$ was put into a crucible, heated at a temperature of $105^{\circ} \mathrm{C}$ for one hour, then cooled and weighed as $\mathrm{W}_{1}$. The crucible containing the sample was placed into a desiccator and then vacuumed. Ammonia was heated then flowed the vapor into a desiccator. The sample was allowed to stand for 24 $\mathrm{h}$ and then weighed as $\mathrm{W}_{2}$ [17]. The acidity test was determined using $\mathrm{NH}_{3}$ as a basic probe molecule. The total amount of adsorbed ammonia was calculated using the following equation:

Total acidity $\left(\mathrm{mmol} \mathrm{g}^{-1}\right)=\frac{\mathrm{W}_{2}-\mathrm{W}_{1}}{\left(\mathrm{~W}_{1}-\mathrm{W}_{0}\right) \times \mathrm{Mr} \mathrm{NH}_{3}} \times 1000$

The catalyst basicity test was carried out using an acid-base titration method. A sample of $0.1 \mathrm{~g}$ was mixed with $10 \mathrm{~mL}$ of distilled water. The mixture was stirred using a magnetic stirrer for one hour. 3-5 drops of phenolphthalein indicator were added and titrated using $0.01 \mathrm{M} \mathrm{HCl}$. The titration was carried out until it reached the equivalence point and was repeated three times. The total volume of $\mathrm{HCl}$ in $\mathrm{mL}$ has been obtained was entered into Eq. (2) to obtain the total basicity of the catalyst [33].

Total basicity $\left(\mathrm{mmol} \mathrm{g}^{-1}\right)=\frac{\mathrm{V}_{\mathrm{HCl}}(\mathrm{mL}) \times \mathrm{M}_{\mathrm{HCl}}(\mathrm{M})}{\text { mass of catalyst }(\mathrm{g})}$

The $\mathrm{SO}_{4}{ }^{2-} / \mathrm{ZrO}_{2}$ catalyst with the highest total acidity and the $\mathrm{Na}_{2} \mathrm{O} / \mathrm{ZrO}_{2}$ catalyst with the highest total basicity calcined at various temperatures of 400, 500, 600, 700, and $800{ }^{\circ} \mathrm{C}$, then characterized using X-Ray Diffractometer (XRD, X PHILIPS XPert MPD). The catalyst was ground to a fine powder then placed into a sample holder. Diffractogram was recorded at $2 \theta=10-45^{\circ}$ using XRD with an X-ray source of $\mathrm{Cu}$ Ka radiation $(\lambda=1.5406 \AA)$.

The calcined catalyst with the highest total acidity and basicity was characterized using SEM combined with EDX and Surface Area Analyzer (SSA). The analysis of surface topography and composition of the catalyst was carried out with SEM (JEOL JSM-6510) equipped with an EDS (JED-2300 Analysis Station) spectrometer. Carbon tape was attached on the sample stage, and the catalyst powder was placed on the carbon tape then vacuumed. The energy resolution was $200 \mathrm{eV}$. The pressure of the SEM chamber was about $10^{-3} \mathrm{~Pa}$. The accelerating voltage was set to $15 \mathrm{kV}$. The probe current was set to $10 \mathrm{nA}$. The SEM-EDX analysis was set to $300 \mathrm{sec}$. The specific surface area and pore size analysis were performed using Quadrasorb EVO Model QDS-30. The catalyst was loaded into analysis stations. The catalyst was degasified to free surfaces from contaminants such as water and oils under a vacuum. The sample was brought to a constant temperature. Then, nitrogen gas flowed to the sample chamber.

\section{The esterification reaction using $\mathrm{SO}_{4}{ }^{2-} / \mathrm{ZrO}_{2}$ solid acid catalyst}

The raw material of LGCPO was heated at $105^{\circ} \mathrm{C}$ to vaporize water and filtered to remove impurities. The molecular weight of LGCPO was determined by saponification, while the concentration of FFA in LGCPO was determined by titration method using a $\mathrm{KOH}$ solution [34-35]. The $\mathrm{SO}_{4}{ }^{2-} / \mathrm{ZrO}_{2}$ solid acid catalyst has the highest total acidity applied in the esterification reaction.

Optimization of esterification conditions was carried out on three different parameters on wt.\% catalyst, the molar ratio of LGCPO to methanol, and reaction time. The $\mathrm{SO}_{4}{ }^{2-} / \mathrm{ZrO}_{2}$ solid acid catalyst on 1,3 , 5 , and $7 \mathrm{wt} . \%$ of the total mass of LGCPO and methanol with the molar ratio of LGCPO: methanol = 1:9 inserted into a three-necked round-bottom flask, followed by methanol at the molar ratio LGCPO: methanol $=1: 9$. The mixture was magnetically stirred at $600 \mathrm{rpm}$ in an oil bath, maintaining a constant temperature of $45^{\circ} \mathrm{C}$ for $10 \mathrm{~min}$. Then $25 \mathrm{~g} \mathrm{LGCPO}$ was added to the mixture, and the reaction was continued at $55^{\circ} \mathrm{C}$ for $20 \mathrm{~min}$. The study of the effect of the molar ratio of LGCPO to methanol on \%FFA LGCPO was conducted on ratios of $1: 3,1: 6$, and 1:12, and reaction times varied for 40 and 60 min. Free Fatty Acid concentrations contained in esterified oil were determined, and the reduction of FFA (\%) was calculated using Eq. (3) [36].

FFA Reduction (\%)

$$
=\frac{\% \text { FFA LGCPO }-\% \text { FFA esterified oil }}{\% \text { FFA LGCPO }} \times 100 \%
$$




\section{Transesterification reaction using $\mathrm{Na}_{2} \mathrm{O} / \mathrm{ZrO}_{2}$ solid base catalyst}

The $\mathrm{Na}_{2} \mathrm{O} / \mathrm{ZrO}_{2}$ solid base catalyst with $7 \mathrm{wt}$. $\%$ of the total mass of LGCPO and methanol with the molar ratio of LGCPO: methanol = 1:24 inserted into a three-necked round-bottom flask, followed by methanol at the molar ratio LGCPO: methanol $=1: 24$. The mixture was magnetically stirred at $600 \mathrm{rpm}$ in an oil bath, maintaining a constant temperature of $45^{\circ} \mathrm{C}$ for $10 \mathrm{~min}$. Then, $20 \mathrm{~g}$ esterified oil was added to the mixture, and the reaction was continued at $55^{\circ} \mathrm{C}$ for $20 \mathrm{~min}$.

The transesterification compound was characterized using FTIR and analyzed using Gas Chromatography-Mass Spectrometer (GC-MS, Shimadzu QP2010S). The formed methyl ester was analyzed using Proton Nuclear Magnetic Resonance Spectrometer $\left({ }^{1} \mathrm{H}-\mathrm{NMR}\right.$, NMR JEOL NMR $\left.500 \mathrm{MHz}\right)$ to identify the \%conversion of methyl ester $\left(\mathrm{C}_{\mathrm{ME}}\right)$, which was calculated based on the proton integration of proton between triglycerides $\left(\mathrm{I}_{\mathrm{TAG}}\right)$ with a methoxy $\left(\mathrm{I}_{\mathrm{ME}}\right)$ using Eq. (4) [37].

$\mathrm{C}_{\mathrm{ME}}=100 \times \frac{5 \times \mathrm{I}_{\mathrm{ME}}}{5 \times \mathrm{I}_{\mathrm{ME}}+9 \times \mathrm{I}_{\mathrm{TAG}}}$

\section{- RESULTS AND DISCUSSION}

\section{Synthesis and Characterization of $\mathrm{SO}_{4}{ }^{2-} / \mathrm{ZrO}_{2}$ Solid Acid Catalysts}

Catalyst synthesis studies on various $\mathrm{H}_{2} \mathrm{SO}_{4}$ concentrations were conducted to determine the effect of the concentration of $\mathrm{H}_{2} \mathrm{SO}_{4}$ on the acidity properties of the catalyst. Characterization using FTIR explains the existence of a functional group owned by a material. Fig. 1 gives information on the differences in the absorption peaks for each catalyst. The absorption of the functional sulfate group belongs to the wavenumber of 750$1350 \mathrm{~cm}^{-1}$. Absorption at that wavenumber is characteristic of inorganic chelate formation where sulfate ions bidentate coordinate with metal cation [38].

The sharpness of the peak for the three catalysts at wavenumbers between $1000-1300 \mathrm{~cm}^{-1}$ looks fluctuating. The absorption peak of catalyst at a concentration of 0.5 $\mathrm{M} \mathrm{H}_{2} \mathrm{SO}_{4}$ looks sharper than the others, but the decline in transmittance is followed by a decrease in transmittance at other wavenumbers. These indications do not show the catalyst acidity with a concentration of $\mathrm{H}_{2} \mathrm{SO}_{4} 0.5 \mathrm{M}$ greater than $0.7 \mathrm{M}$ due to decreased transmittance on the spectra. On the other hand, the absorption of $\mathrm{ZrO}_{2}$ catalyst with a concentration of $\mathrm{H}_{2} \mathrm{SO}_{4} 0.7 \mathrm{M}$ appears blunter than other catalysts. It can be analyzed that the vibrations which tend to be detected are sulfate groups dispersed on $\mathrm{ZrO}_{2}$. Pavia et al. [39] explained that the vibration of the $\mathrm{S}-\mathrm{O}$ bond of the sulfonate group was in the absorption band $1000-750 \mathrm{~cm}^{-1}$, which was marked by the appearance of several peaks, whereas the $\mathrm{S}=\mathrm{O}$ bond had asymmetric and symmetry stretch vibrations detected at 1350 and $1175 \mathrm{~cm}^{-1}$, respectively.

The results of the acidity test on various $\mathrm{H}_{2} \mathrm{SO}_{4}$ concentrations are listed in Table 1 to strengthen the analysis. The total acidity is obtained from the number of ammonia bases absorbed in the catalyst. Total acidity is defined as the total number of sites of Brønsted and Lewis acids in $\mathrm{mmol} \mathrm{g}^{-1}$. Catalysts synthesized using

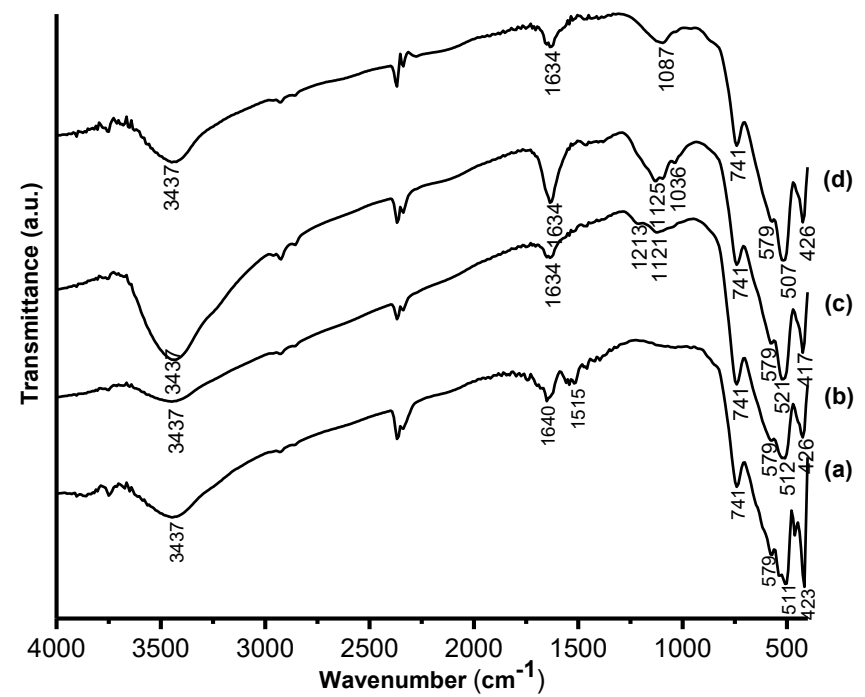

Fig 1. FTIR spectra of (a) $\mathrm{ZrO}_{2}$ and $\mathrm{SO}_{4}{ }^{2-} / \mathrm{ZrO}_{2} 60^{\circ} \mathrm{C} ; 24$ h catalyst on various $\mathrm{H}_{2} \mathrm{SO}_{4}$ concentration (b) $0.3 \mathrm{M}$, (c) $0.5 \mathrm{M}$, and (d) $0.7 \mathrm{M}$

Table 1. The result of the acidity test of $\mathrm{SO}_{4}{ }^{2-} / \mathrm{ZrO}_{2}$ catalyst on various $\mathrm{H}_{2} \mathrm{SO}_{4}$ concentrations

\begin{tabular}{lc}
\hline Catalyst & Total acidity $\left(\mathrm{mmol} \mathrm{g}^{-1}\right)$ \\
\hline $0.3 \mathrm{M} \mathrm{SO}_{4}{ }^{2-} / \mathrm{ZrO}_{2} 60^{\circ} \mathrm{C} ; 24 \mathrm{~h}$ & 0.68 \\
$0.5 \mathrm{M} \mathrm{SO}_{4}{ }^{2-} / \mathrm{ZrO}_{2} 60^{\circ} \mathrm{C} ; 24 \mathrm{~h}$ & 1.35 \\
$0.7 \mathrm{M} \mathrm{SO}_{4}{ }^{2-} / \mathrm{ZrO}_{2} 60^{\circ} \mathrm{C} ; 24 \mathrm{~h}$ & 1.86 \\
\hline
\end{tabular}


$\mathrm{H}_{2} \mathrm{SO}_{4} 0.7 \mathrm{M}$ has a total acidity of $1.86 \mathrm{mmol} \mathrm{g}^{-1}$. That acidity value is higher than $\mathrm{ZrO}_{2}$, with a total acidity of $0.06 \mathrm{mmol} \mathrm{g}^{-1}$. The results show that a greater concentration of sulfuric acid increases the total acidity. Increased total acidity correlated with the formation of the number of acid sites. The addition of $\mathrm{H}_{2} \mathrm{SO}_{4}$ will initiate the formation of sulfate ion coordination to the $\mathrm{Zr}$ site. The coordination of sulfate groups on $\mathrm{ZrO}_{2}$ adds acidic sites to the surface. The super acidic properties of this material can be related to the formation of $S=O$, which is naturally formed in the complex due to the interaction between $\mathrm{ZrO}_{2}$ and sulfate ions so that the $\mathrm{S}=\mathrm{O}$ group provides a strong induction effect [21].

The study of the effect of calcination temperature aims to determine the $\mathrm{ZrO}_{2}$ crystal phase transformation. The results of FTIR characterization of $0.7 \mathrm{M} \mathrm{SO}_{4}{ }^{2-} / \mathrm{ZrO}_{2}$ $60{ }^{\circ} \mathrm{C} ; 24 \mathrm{~h}$ catalyst on various calcination temperatures are shown in Fig. 2. The absorption bands at the wavenumbers of $429,518,585,740,1633$, and $3426 \mathrm{~cm}^{-1}$ are detected on each catalyst. The FTIR spectra of the catalyst after sulfonation can be observed with the appearance of an absorption band at the wavenumber $1045 \mathrm{~cm}^{-1}$, which is the vibration of the $\mathrm{O}=\mathrm{S}=\mathrm{O}$ group [40]. The vibration of the $-\mathrm{SO}_{3} \mathrm{H}$ group is detected at $1149 \mathrm{~cm}^{-1}$. The absorption band at $1237 \mathrm{~cm}^{-1}$ is the vibration of S-O [41]. The appearance of absorption at $3426 \mathrm{~cm}^{-1}$ is suspected of the vibration from the $-\mathrm{SO}_{2} \mathrm{OH}$ group [42]. The absorption bands at 990, 1050-1060, $1130-1140$, and $1220-1230 \mathrm{~cm}^{-1}$ indicate the coordination of sulfate bidental ion in $\mathrm{Zr}^{4+}$. The FTIR spectra do not show that the existence of that group significantly changes after being calcined.

The results of the acidity test of the catalysts in various calcination temperatures are displayed in Table 2. The total acidity of the catalyst decreases as the calcination temperature increases. These changes indicate a strong interaction between sulfate anion with $\mathrm{ZrO}_{2}$ [43]. Sulfur is estimated to reach the highest oxidation level of $\mathrm{S}^{6+}$ as $\mathrm{SO}_{4}{ }^{2-}$ as the main species when heated. The increase in heat energy will break the bond between sulfate and $\mathrm{ZrO}_{2}$, so catalyst acidity decreases.

The catalyst phase structure influences the selectivity of chemical reactions. Zirconium dioxide in the tetragonal phase is more sensitive than $\mathrm{ZrO}_{2}$ in the monoclinic phase. In addition, the specific surface area and appropriate pore size also affect the performance of catalysts in reaction. Sulfate anions that enter the zirconia framework can increase the thermal stability of the material. Incorporating a functional acid group can improve the catalytic acid site to be used as a catalyst in biodiesel production [16].

Adsorption of oxygen ions on the surface of $\mathrm{ZrO}_{2}$ can trigger phase transformation [23]. Shi et al. [38] explained that the monoclinic crystal phase is very influential in impregnating sulfate groups on the zirconia surfaces. This influence is related to the inhibition of $\mathrm{Zr}^{3+}$ formation in the monoclinic phase. The formation of $\mathrm{Zr}^{3+}$ can occur in the presence of an oxygen vacancy in the tetragonal phase. Thus, more sulfate groups can bind to the surface of the zirconia. The more sulfate groups that can be impregnated, the acidity site will increase along with the increased catalysis activity [38].

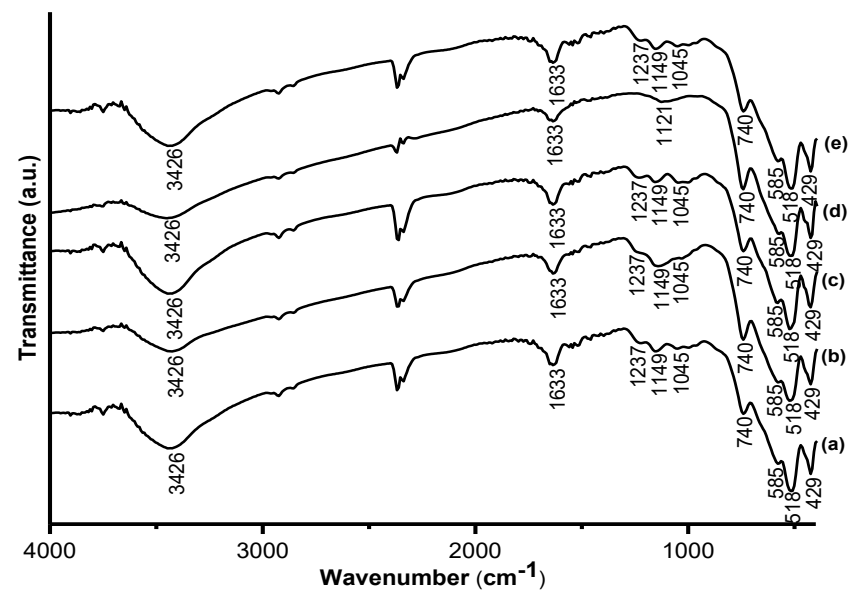

Fig 2. FTIR spectra of $0.7 \mathrm{M} \mathrm{SO}_{4}{ }^{2-} / \mathrm{ZrO}_{2} 60^{\circ} \mathrm{C} ; 24 \mathrm{~h}$ catalyst on various calcination temperature (a) 400 , (b) 500, (c) 600, (d) 700 , and (e) $800{ }^{\circ} \mathrm{C}$

Table 2. The result of the acidity test of $0.7 \mathrm{M} \mathrm{SO}_{4}{ }^{2-} / \mathrm{ZrO}_{2}$ $60^{\circ} \mathrm{C} ; 24 \mathrm{~h}$ catalyst on the various calcination temperature

\begin{tabular}{lc}
\hline Catalyst & Total acidity $\left(\mathrm{mmol} \mathrm{g}^{-1}\right)$ \\
\hline $0.7 \mathrm{M} \mathrm{SO}_{4}{ }^{2-} / \mathrm{ZrO}_{2}-400$ & 0.67 \\
$0.7 \mathrm{M} \mathrm{SO}_{4}{ }^{2-} / \mathrm{ZrO}_{2}-500$ & 0.46 \\
$0.7 \mathrm{M} \mathrm{SO}_{4}{ }^{2-} / \mathrm{ZrO}_{2}-600$ & 0.24 \\
$0.7 \mathrm{M} \mathrm{SO}_{4}{ }^{2-} / \mathrm{ZrO}_{2}-700$ & 0.12 \\
$0.7 \mathrm{M} \mathrm{SO}_{4}{ }^{2-} / \mathrm{ZrO}_{2}-800$ & 0.11 \\
\hline
\end{tabular}


The result of the catalyst characterization using the XRD is shown in Fig. 3. Based on PDF 01-089-9066, the entire peaks appear on the XRD patterns showing a monoclinic $\mathrm{ZrO}_{2}$. Increasing temperature up to $800{ }^{\circ} \mathrm{C}$ does not change the catalyst phase $0.7 \mathrm{M} \mathrm{SO}_{4}{ }^{2-} / \mathrm{ZrO}_{2}$. No significant changes can be observed at $2 \theta=28.21^{\circ}$ and $31.46^{\circ}[44]$.

Morphology of $\mathrm{ZrO}_{2}$ and $0.7 \mathrm{M} \mathrm{SO}_{4}{ }^{2-} / \mathrm{ZrO}_{2} 60^{\circ} \mathrm{C} ; 24$ $\mathrm{h}$ catalyst are shown in Fig. 4. $\mathrm{ZrO}_{2}$ has an irregular shape. The size of the material becomes smaller and uniform, with an imperfect round shape after sulfation. Spherical particles tend to have good reactant transport properties. The use of strong acids triggers framework shrinkage and damage some bonds, resulting in smaller particle sizes and changes in passageways between materials. Based on the results of the EDS compiled in Table 3, the sulfur on the surface of $\mathrm{ZrO}_{2}$ reached $1.07 \%$. The dot mapping results show that the sulfur element is evenly distributed and does not show clumping on any particular side.

The performance of this catalyst is determined by the strength and accessibility of the active acid site to large compounds such as triglycerides and FFA [45]. The physical properties of the catalyst obtained using $\mathrm{N}_{2}$ adsorption and pore size analysis of the catalyst are summarized in Table 3. Based on these results, it can be seen that the incorporation of sulfuric acid groups in

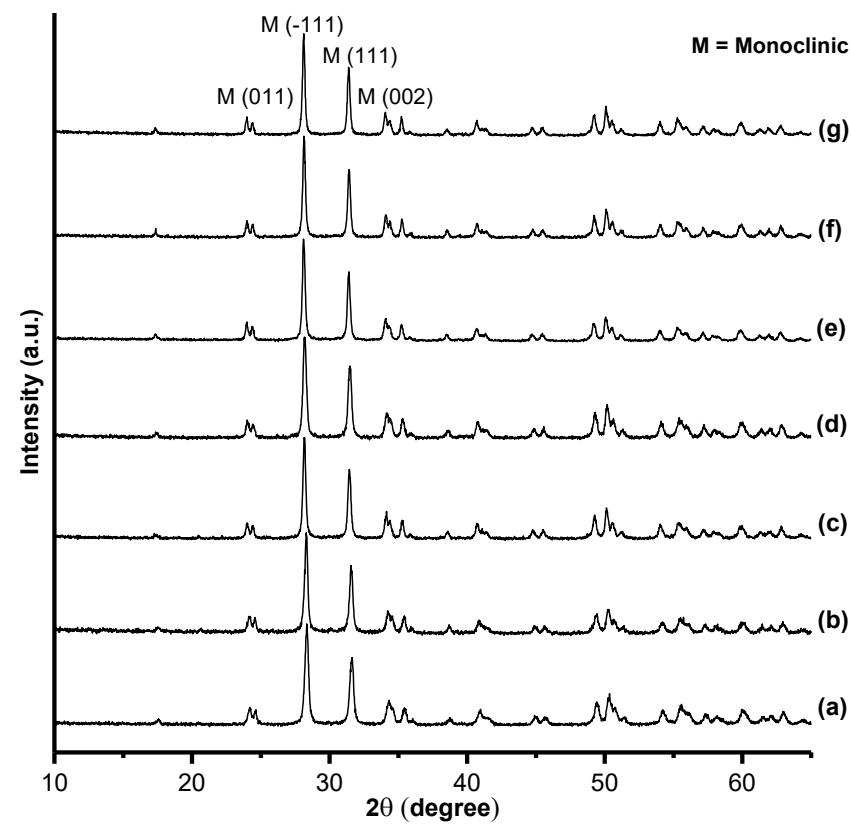

Fig 3. The XRD patterns of catalyst (a) $\mathrm{ZrO}_{2}$, (b) $0.7 \mathrm{M}$ $\mathrm{SO}_{4}{ }^{2-} / \mathrm{ZrO}_{2} 60^{\circ} \mathrm{C} ; 24 \mathrm{~h}$ at the calcination temperature (c) 400, (d) 500, (e) 600, (f) 700, and (g) $800{ }^{\circ} \mathrm{C}$

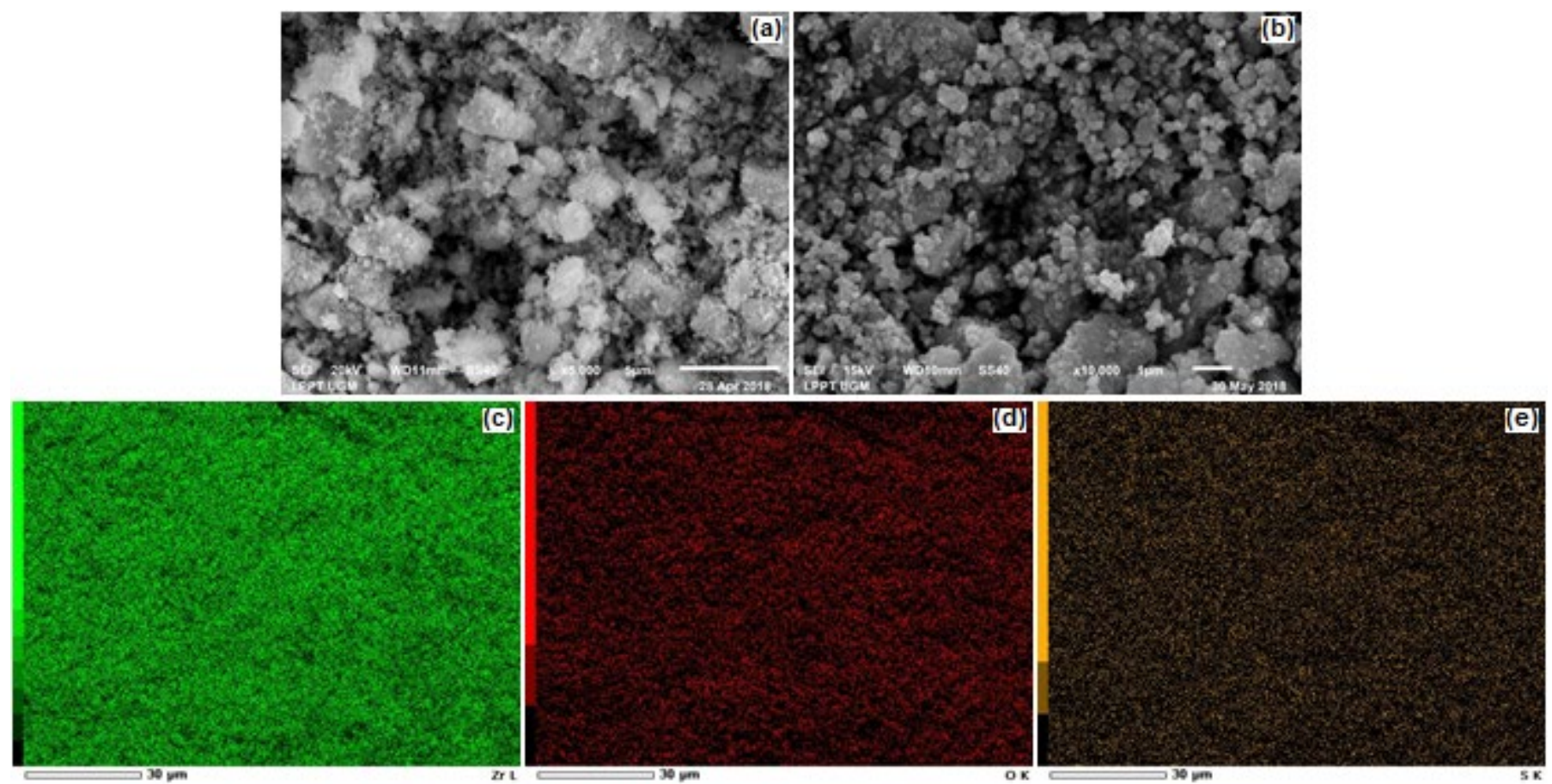

Fig 4. SEM images of catalyst (a) $\mathrm{ZrO}_{2}$ at magnification $5000 \times$, (b) $0.7 \mathrm{M} \mathrm{SO}_{4}{ }^{2-} / \mathrm{ZrO}_{2} 60{ }^{\circ} \mathrm{C} ; 24 \mathrm{~h}$ at magnification $10.000 \times$, the dot mapping element of (c) zirconium (d) oxygen and (e) sulfur 
Table 3. The elemental composition and surface area analysis of the acid catalyst

\begin{tabular}{|c|c|c|c|c|c|c|}
\hline \multirow[b]{2}{*}{ Catalyst } & \multicolumn{3}{|c|}{$\%$ of Element mass } & \multicolumn{3}{|c|}{ Properties } \\
\hline & $\mathrm{Zr}$ & $\mathrm{O}$ & S & $\begin{array}{c}\mathrm{S}_{\mathrm{BET}}{ }^{\mathrm{a}} \\
\left(\mathrm{m}^{2} \mathrm{~g}^{-1}\right)\end{array}$ & $\begin{array}{c}\mathrm{V}_{\mathrm{p}}^{\mathrm{b}} \\
\left(\mathrm{cm}^{3} \mathrm{~g}^{-1}\right)\end{array}$ & $\begin{array}{l}\mathrm{D}_{\mathrm{p}}{ }^{\mathrm{c}} \\
(\AA)\end{array}$ \\
\hline $\mathrm{ZrO}_{2}$ & 69.67 & 25.20 & - & 13.95 & $1.74 \times 10^{-2}$ & 25.02 \\
\hline $0.7 \mathrm{M} \mathrm{SO}_{4}{ }^{2-} / \mathrm{ZrO}_{2} 60^{\circ} \mathrm{C} ; 24 \mathrm{~h}$ & 64.52 & 28.48 & 1.07 & 9.21 & $1.25 \times 10^{-2}$ & 27.19 \\
\hline
\end{tabular}

zirconia decreases the pore volume and surface area of the sulfated zirconia catalyst. The surface area of the catalyst decreased to $9.21 \mathrm{~m}^{2} \mathrm{~g}^{-1}$. The sulfur element has a diameter of $1.02 \AA$. An increase in pore diameter is possible due to damage to the structure by acids and the formation of bonds between $\mathrm{S}$ and $\mathrm{ZrO}_{2}$. The interaction between sulfate ions and $\mathrm{ZrO}_{2}$ protects the catalyst from sintering [21].

The pore size of the synthesized catalyst is around $27.19 \AA$ A. Triglyceride molecules have a dimension of $2.5 \mathrm{~nm}$ and can easily fit into the internal surface of the catalyst so that the reaction can take place on the entire catalyst's active site. Large reactants such as triglycerides are not restricted to access catalytic sites. Catalytic activity occurs on external and internal surfaces [31].

\section{Application of $\mathrm{SO}_{4}{ }^{2-} / \mathrm{ZrO}_{2}$ Solid Acid Catalyst on Esterification Reactions}

Esterification is part of an organic reaction that aims to form an ester of a mixture of acid and alcohol. In this research, biodiesel was made from the raw material of LGCPO. LGCPO was produced from the palm oil industry, so it needs to be filtered and evaporated. A heterogeneous catalyst is easily degraded by $\mathrm{H}_{2} \mathrm{O}$ [3]. The presence of water acts as an impurity. Water will block the active site of the catalyst, which causes its catalytic activity to diminish. Triglycerides will be hydrolyzed to form glycerol and FFA. FFA in LGCPO will react with a basic catalyst to form soap which deactivates the catalyst and makes the separation process more difficult. The scheme of triglycerides hydrolysis is illustrated in Fig. 5.

\section{Effect of wt.\% catalyst on \%FFA LGCPO}

The concentration of FFA is denoted in \%FFA. The FFA concentration in the LGCPO is $1.40 \%$. \%FFA of each reaction at various conditions is presented in Table 4 . There

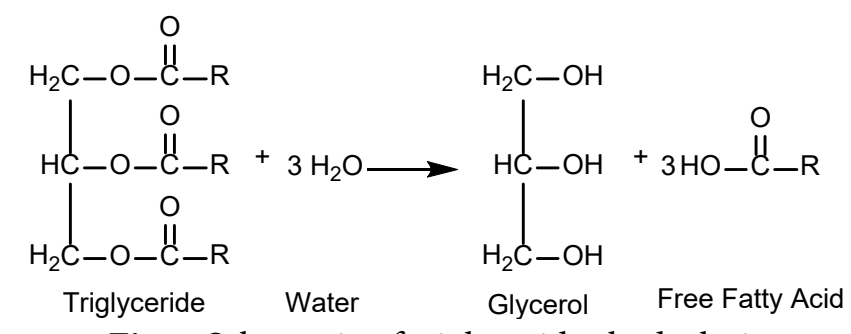

Fig 5. Schematic of triglycerides hydrolysis

is a tendency that shows an increase in wt.\% of the catalyst inversely with \%FFA. The more amount of catalysts used, the lower the acidity of the oil. The lowest \%FFA is obtained when the wt.\% of catalyst used is $7 \%$. The esterification reaction that took place using $7 \mathrm{wt} . \%$ of catalyst can reduce acidity by $58.01 \%$. Decreasing oil acidity can be attributed to the conversion of FFA to ester. The greater the number of catalysts, the more catalytic's active sites are available for the reaction.

\section{Effect of the molar ratio of LGCPO to methanol on \%FFA LGCPO}

The molar ratio of LGCPO to methanol is a factor that influences the reduction of FFA concentration. The addition of excess alcohol can accelerate the reaction and is preferred in the formation of biodiesel. Theoretically, the formation of one mole Fatty Acid Methyl Esters (FAME) and one mole of water requires one mole of methanol and one mole of FFA. Excess methanol is needed so the reaction equilibrium shifts towards the product, updating the catalyst surface by removing water molecules from surfaces and regenerating catalytic sites [10,31].

The reduction of \%FFA is directly proportional to the molar ratio of methanol. A significant reduction in \%FFA is observed at a molar ratio of 1:6. At larger ratios, the FFA decreases until it reaches a maximum reduction 
Table 4. The results of \%FFA LGCPO in the esterification reaction on various parameters

\begin{tabular}{|c|c|c|c|c|}
\hline \multirow[b]{2}{*}{ Catalyst type } & \multicolumn{3}{|c|}{ Reaction parameters } & \multirow{2}{*}{$\begin{array}{c}\text { FFA concentration } \\
(\%)\end{array}$} \\
\hline & $\begin{array}{c}\text { wt.\% Catalyst } \\
(\%)\end{array}$ & $\begin{array}{c}\text { Molar ratio } \\
\text { LGCPO:methanol }\end{array}$ & $\begin{array}{l}\text { Reaction time } \\
(\min )\end{array}$ & \\
\hline Without catalyst & - & $1: 12$ & 20 & 1.24 \\
\hline $\mathrm{ZrO}_{2}$ & 7 & $1: 12$ & 20 & 1.08 \\
\hline $0.7 \mathrm{M} \mathrm{SO}_{4}{ }^{2-} / \mathrm{ZrO}_{2} 60^{\circ} \mathrm{C} ; 24 \mathrm{~h}$ & 1 & $1: 9$ & 20 & 1.10 \\
\hline $0.7 \mathrm{M} \mathrm{SO}_{4}{ }^{2-} / \mathrm{ZrO}_{2} 60^{\circ} \mathrm{C} ; 24 \mathrm{~h}$ & 3 & $1: 9$ & 20 & 0.85 \\
\hline $0.7 \mathrm{M} \mathrm{SO}_{4}^{2-} / \mathrm{ZrO}_{2} 60^{\circ} \mathrm{C} ; 24 \mathrm{~h}$ & 5 & $1: 9$ & 20 & 0.81 \\
\hline $0.7 \mathrm{M} \mathrm{SO}_{4}^{2-} / \mathrm{ZrO}_{2} 60^{\circ} \mathrm{C} ; 24 \mathrm{~h}$ & 7 & $1: 3$ & 20 & 1.24 \\
\hline $0.7 \mathrm{M} \mathrm{SO}_{4}^{2-} / \mathrm{ZrO}_{2} 60^{\circ} \mathrm{C} ; 24 \mathrm{~h}$ & 7 & $1: 6$ & 20 & 0.68 \\
\hline $0.7 \mathrm{M} \mathrm{SO}_{4}{ }^{2-} / \mathrm{ZrO}_{2} 60^{\circ} \mathrm{C} ; 24 \mathrm{~h}$ & 7 & $1: 9$ & 20 & 0.59 \\
\hline $0.7 \mathrm{M} \mathrm{SO}_{4}{ }^{2-} / \mathrm{ZrO}_{2} 60^{\circ} \mathrm{C} ; 24 \mathrm{~h}$ & 7 & $1: 12$ & 20 & 0.44 \\
\hline $0.7 \mathrm{M} \mathrm{SO}_{4}{ }^{2-} / \mathrm{ZrO}_{2} 60^{\circ} \mathrm{C} ; 24 \mathrm{~h}$ & 7 & $1: 12$ & 40 & 0.58 \\
\hline $0.7 \mathrm{M} \mathrm{SO}_{4}^{2-} / \mathrm{ZrO}_{2} 60{ }^{\circ} \mathrm{C} ; 24 \mathrm{~h}$ & 7 & $1: 12$ & 60 & 0.58 \\
\hline $0.7 \mathrm{M} \mathrm{SO}_{4}^{2-} / \mathrm{ZrO}_{2} 60^{\circ} \mathrm{C} ; 24 \mathrm{~h}-500$ & 7 & $1: 12$ & 20 & 1.01 \\
\hline
\end{tabular}

of $68.87 \%$ when the molar ratio was $1: 12$. The more methanol used, the more the formation of methoxy species will be, the reaction will eventually shift towards the product. At low ratios, the produced methoxy ions are also low, so the yield is slight. If the molar ratio is too low, the oil volume fraction in the mixture is high. Then it greatly allows the catalyst to be at the oil phase. The oil covers the catalyst surface then reduces the formation of methoxy ions so that the yield decreases. The oil and methanol interface areas depend on the dispersion of these solutions with each other [46]. Improved interface area makes it easier to transfer methoxy ions faster from the aqueous phase to the organic phase.

\section{Effect of reaction time on \%FFA LGCPO}

The influence of time reaction was carried out for 20,40 , and $60 \mathrm{~min}$. The addition of reaction time does not give a significant reduction. The best reduction of $\% \mathrm{FFA}$ lasts for $20 \mathrm{~min}$, giving a decline of $68.87 \%$. Mass transfer between oil and alcohol will increase when the given residence time is longer [10]. The optimum time needed in this reaction is $20 \mathrm{~min}$. The mixture is sufficiently dispersed during this time. Increasing the reaction time will shift the equilibrium towards the reactants because the reaction is reversible and triggers the deactivation of the $-\mathrm{SO}_{3} \mathrm{H}$ acid site due to bonds with a polar molecule from reaction mixtures such as $\mathrm{H}_{2} \mathrm{O}$ [42]. The prediction of the mechanism of esterification reaction on $\mathrm{SO}_{4}{ }^{2-}$ $/ \mathrm{ZrO}_{2}$ solid acid catalyst are shown in Fig. 6 and 7.

The esterification reaction is carried out under different conditions to examine the performance of the catalyst [47]. The reaction within $20 \mathrm{~min}$ without a catalyst resulted in an $11.24 \%$ reduction. Sulfated zirconia can reduce FFA up to $68.87 \%$. This value shows that $\mathrm{SO}_{4}{ }^{2-} / \mathrm{ZrO}_{2}$ catalyst has better performance than $\mathrm{ZrO}_{2}$. Therefore, it can be confirmed that modification using $\mathrm{H}_{2} \mathrm{SO}_{4}$ improves catalyst performance. The \%FFA test results show that the performance of the $\mathrm{SO}_{4}{ }^{2-} / \mathrm{ZrO}_{2}$ catalyst calcined at $500^{\circ} \mathrm{C}$ decreased. This data supports that the acidity of the catalyst greatly influences the catalyst performance.

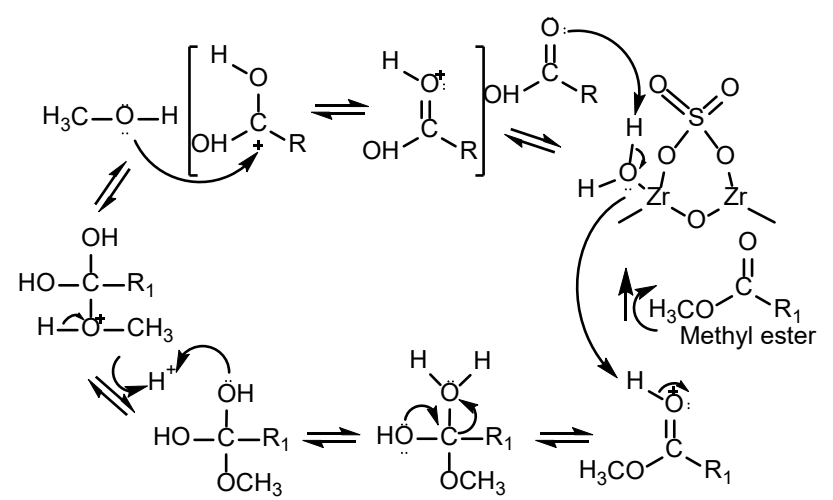

Fig 6. Prediction of the esterification reaction mechanism on Brønsted acid site of $\mathrm{SO}_{4}{ }^{2-} / \mathrm{ZrO}_{2}$ solid acid catalyst 


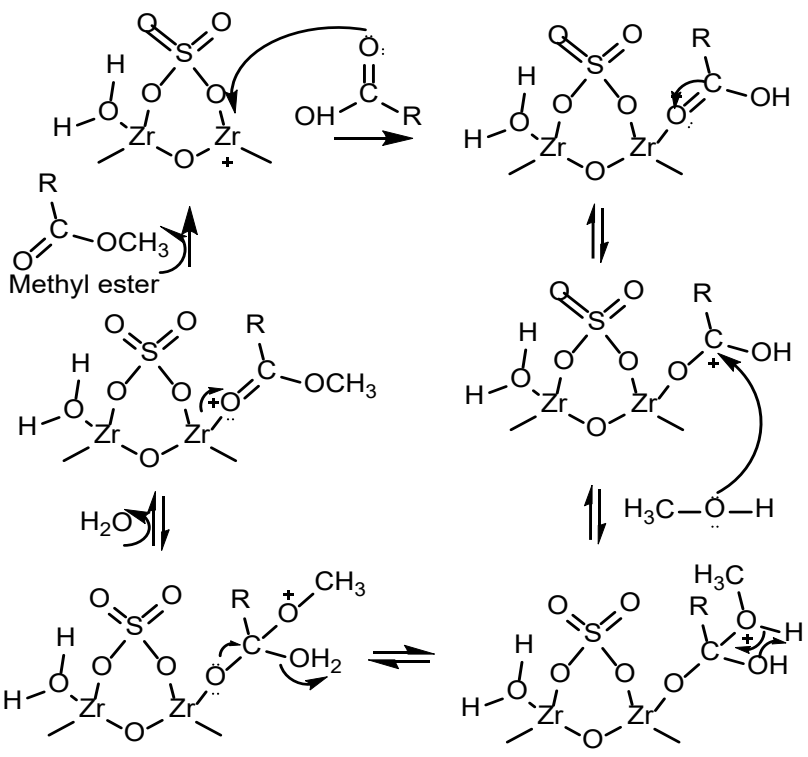

Fig 7. Prediction of the esterification reaction mechanism on Lewis acid site of $\mathrm{SO}_{4}{ }^{2-} / \mathrm{ZrO}_{2}$ solid acid catalyst

\section{Synthesis and Characterization of $\mathrm{Na}_{2} \mathrm{O} / \mathrm{ZrO}_{2}$ Solid Base Catalysts}

Characterization of the catalyst using FTIR on various $\mathrm{NaOH}$ concentrations is shown in Fig. 8. This study is carried out to determine the effect of the amount of $\mathrm{NaOH}$ on the basic properties of the base catalyst. The FTIR spectra show that each catalyst has absorption at wavenumbers $422,500,583,745,871,1455,1637$, and $3432 \mathrm{~cm}^{-1}$. The $\mathrm{Na}_{2} \mathrm{O} / \mathrm{ZrO}_{2}$ catalyst can absorb $\mathrm{CO}_{2}$ from the environment. The greater concentration of base that is given in the reaction, the more $\mathrm{CO}_{2}$ will be absorbed. As a result, the $\mathrm{CO}_{3}{ }^{2-}$ absorption band appears even sharper. There are several changes observed in Fig. 8. The sharpness of the vibration of $\mathrm{Zr}-\mathrm{O}-\mathrm{Na}$ asymmetry detected at $1637 \mathrm{~cm}^{-1}$ decreases with the increasing concentration of $\mathrm{NaOH}$. This is possibly due to the large addition of $\mathrm{Na}$ covering the substrate surface. Based on Table 5, the catalyst that uses $\mathrm{NaOH} 4 \mathrm{M}$ has the highest total basicity value. The addition of sodium ions triggers the formation of strong basic sites. Active sites increase with the increasing number of alkali metals on $\mathrm{ZrO}_{2}$ [28].

The FTIR spectra of $4 \mathrm{M} \mathrm{Na}_{2} \mathrm{O} / \mathrm{ZrO}_{2} 60{ }^{\circ} \mathrm{C} ; 12 \mathrm{~h}$ catalyst on various calcination temperatures are shown in Fig. 9. Absorption bands at wavenumbers 423, 500, 576, $750,865,1446,1577,2852,2918$, and $3420 \mathrm{~cm}^{-1}$ are detected on each catalysts. In general, there is a tendency that shows a decrease in the sharpness of vibration $\mathrm{CO}_{3}{ }^{2}$. These results are confirmed by the basicity test results given in Table 6, which show that the basicity of the

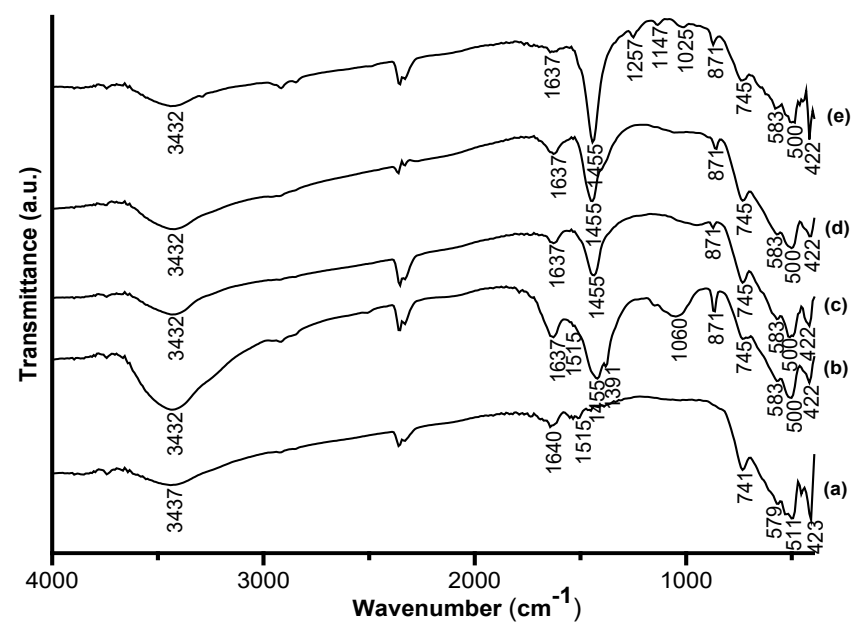

Fig 8. FTIR spectra of (a) $\mathrm{ZrO}_{2}$ and $\mathrm{Na}_{2} \mathrm{O} / \mathrm{ZrO}_{2} 60^{\circ} \mathrm{C} ; 12$ h catalyst on various $\mathrm{NaOH}$ concentration (b) $1 \mathrm{M}$, (c) 2 $\mathrm{M}$, (d) $3 \mathrm{M}$, and (e) $4 \mathrm{M}$

Table 5. The result of basicity test of $\mathrm{Na}_{2} \mathrm{O} / \mathrm{ZrO}_{2}$ catalyst on various $\mathrm{NaOH}$ concentrations

\begin{tabular}{lc}
\hline Catalyst & Total basicity $\left(\mathrm{mmol} \mathrm{g}^{-1}\right)$ \\
\hline $1 \mathrm{M} \mathrm{Na}_{2} \mathrm{O} / \mathrm{ZrO}_{2} 60^{\circ} \mathrm{C} ; 12 \mathrm{~h}$ & $0.56 \pm 0.01$ \\
$2 \mathrm{M} \mathrm{Na}_{2} \mathrm{O} / \mathrm{ZrO}_{2} 60^{\circ} \mathrm{C} ; 12 \mathrm{~h}$ & $1.43 \pm 0.04$ \\
$3 \mathrm{M} \mathrm{Na}_{2} \mathrm{O} / \mathrm{ZrO}_{2} 60^{\circ} \mathrm{C} ; 12 \mathrm{~h}$ & $1.83 \pm 0.02$ \\
$4 \mathrm{M} \mathrm{Na}_{2} \mathrm{O} / \mathrm{ZrO}_{2} 60^{\circ} \mathrm{C} ; 12 \mathrm{~h}$ & $3.75 \pm 0.12$ \\
\hline
\end{tabular}

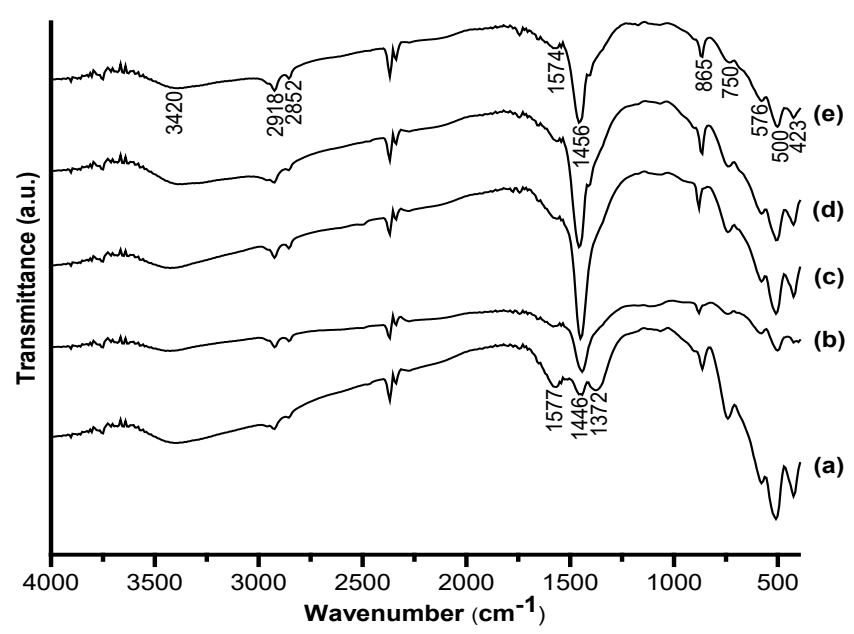

Fig 9. FTIR spectra of $4 \mathrm{M} \mathrm{Na}_{2} \mathrm{O} / \mathrm{ZrO}_{2} 60{ }^{\circ} \mathrm{C} ; 12 \mathrm{~h}$ catalyst on various calcination temperature (a) 400, (b) 500, (c) 600, (d) 700 , and (e) $800^{\circ} \mathrm{C}$ 
catalyst tends to decrease after calcination. The result of catalyst characterization using XRD is shown in Fig. 10. The existence of the monoclinic $\mathrm{ZrO}_{2}$ phase is characterized by the appearance of peaks at $2 \theta=28.21^{\circ}$ and $31.46^{\circ}$. Temperature rising to $800^{\circ} \mathrm{C}$ does not change the catalyst phase.

Fig. 11 shows the SEM image of $4 \mathrm{M} \mathrm{Na}_{2} \mathrm{O} / \mathrm{ZrO}_{2} 60^{\circ} \mathrm{C}$; $12 \mathrm{~h}$ at a magnification of $1000 \times$ and $3000 \times$. The size of the material becomes smaller and uniform with the forms of granules that overlap each other. Based on the results of EDS compiled in Table 7, $\mathrm{Na}$ dispersed on the surface of $\mathrm{ZrO}_{2}$ reached $8.41 \%$. The results of the physical properties characterization of catalysts are reported in Table 7. Based on these results, it can be seen that modified zirconia has decreased pore volume and surface area. The surface area of the modified catalyst has decreased to $10.38 \mathrm{~m}^{2} \mathrm{~g}^{-1}$. These changes are related to changes in the surface of the catalyst. Na covers the surface of the pore of the catalyst [48]. The detected pores are pseudo pores.

\section{Application of $\mathrm{Na}_{2} \mathrm{O} / \mathrm{ZrO}_{2}$ Solid Base Catalyst for Transesterification Reaction}

At this stage, the esterified LGCPO with the lowest FFA concentration is used as a source of triglycerides. The reaction temperature is chosen at the optimum temperature of $55^{\circ} \mathrm{C}$. The optimum temperature is the temperature that closes to the boiling point of methanol, where methanol is

Table 6. The result of basicity test of $4 \mathrm{M} \mathrm{Na}_{2} \mathrm{O} / \mathrm{ZrO}_{2}$ $60{ }^{\circ} \mathrm{C} ; 12 \mathrm{~h}$ catalyst on the various calcination temperature

\begin{tabular}{lc}
\hline Catalyst & Total basicity $\left(\mathrm{mmol} \mathrm{g}^{-1}\right)$ \\
\hline $4 \mathrm{M} \mathrm{Na}_{2} \mathrm{O} / \mathrm{ZrO}_{2}-400$ & $3.07 \pm 1.06$ \\
$4 \mathrm{M} \mathrm{Na}_{2} \mathrm{O} / \mathrm{ZrO}_{2}-500$ & $3.03 \pm 0.06$ \\
$4 \mathrm{M} \mathrm{Na}_{2} \mathrm{O} / \mathrm{ZrO}_{2}-600$ & $2.98 \pm 0.05$ \\
$4 \mathrm{M} \mathrm{Na}_{2} \mathrm{O} / \mathrm{ZrO}_{2}-700$ & $2.68 \pm 0.49$ \\
$4 \mathrm{M} \mathrm{Na}_{2} \mathrm{O} / \mathrm{ZrO}_{2}-800$ & $2.58 \pm 0.07$ \\
\hline
\end{tabular}

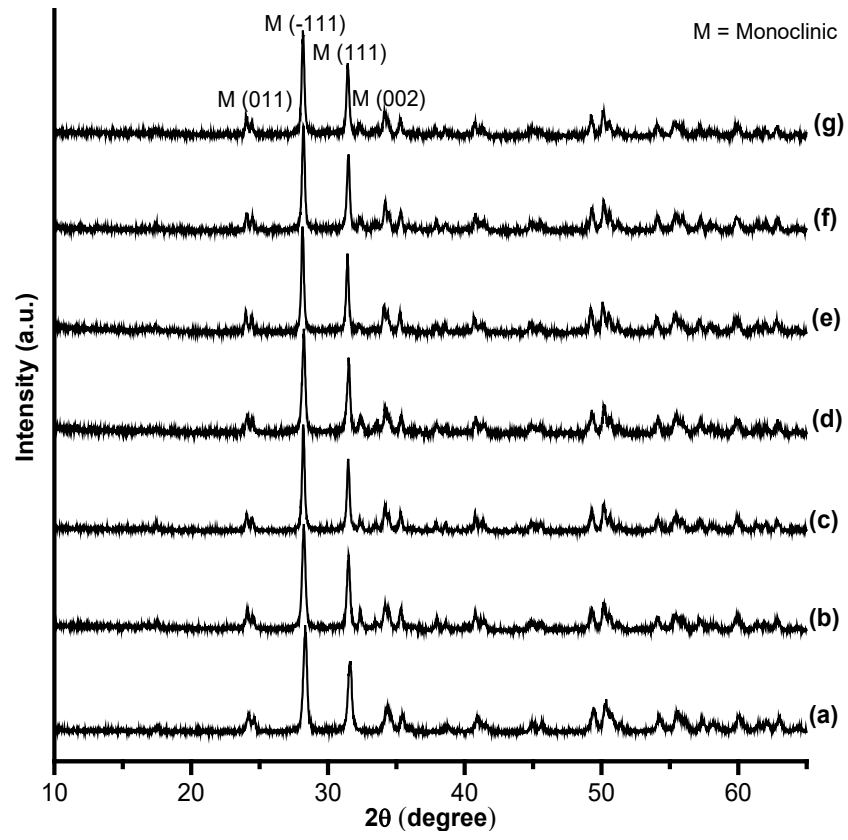

Fig 10. The XRD patterns of catalyst (a) $\mathrm{ZrO}_{2}$, (b) $4 \mathrm{M}$ $\mathrm{Na}_{2} \mathrm{O} / \mathrm{ZrO}_{2} 60{ }^{\circ} \mathrm{C} ; 12 \mathrm{~h}$ at the calcination temperature (c) 400, (d) 500, (e) 600, (f) 700, and (g) $800{ }^{\circ} \mathrm{C}$

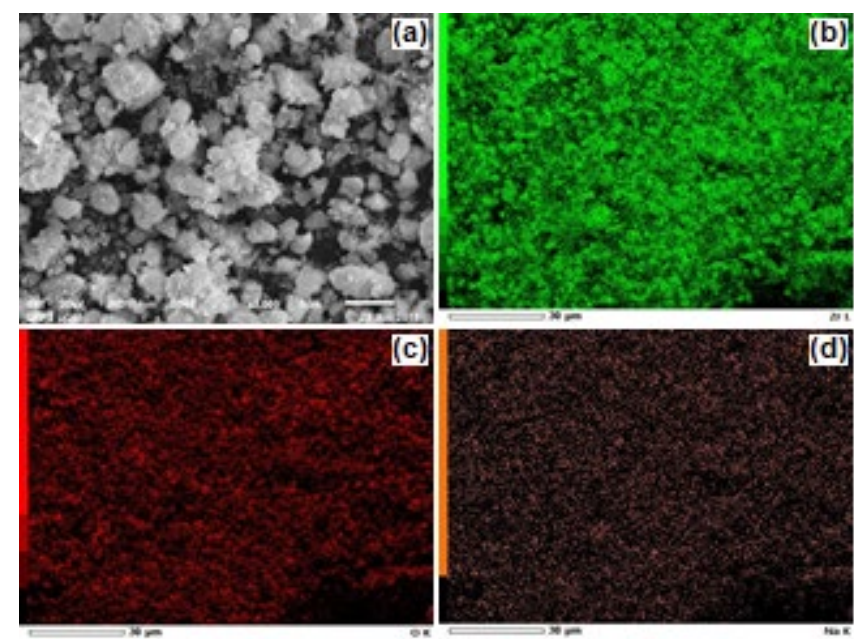

Fig 11. (a) SEM image of $4 \mathrm{M} \mathrm{Na}_{2} \mathrm{O} / \mathrm{ZrO}_{2} 60^{\circ} \mathrm{C} ; 12 \mathrm{~h}$ catalyst at magnification $3000 \times$, the dot mapping element of (b) zirconium (c) oxygen and (d) sodium

Table 7. The elemental composition and surface area analysis of the base catalyst

\begin{tabular}{lcccccc}
\hline & \multicolumn{3}{c}{ \% of Element mass } & \multicolumn{3}{c}{ Properties } \\
\cline { 2 - 7 } Catalyst & $\mathrm{Zr}$ & $\mathrm{O}$ & $\mathrm{Na}$ & $\begin{array}{c}\mathrm{S}_{\mathrm{BET}}{ }^{\mathrm{a}} \\
\left(\mathrm{m}^{2} \mathrm{~g}^{-1}\right)\end{array}$ & $\begin{array}{c}\mathrm{V}_{\mathrm{p}}{ }^{\mathrm{b}} \\
\left(\mathrm{cm}^{3} \mathrm{~g}^{-1}\right)\end{array}$ & $\begin{array}{c}\mathrm{D}_{\mathrm{p}}{ }^{\mathrm{c}} \\
(\AA)\end{array}$ \\
\hline $\mathrm{ZrO}_{2}$ & 69.67 & 25.20 & - & 13.95 & $1.74 \times 10^{-2}$ & 25.02 \\
$4 \mathrm{M} \mathrm{Na}_{2} \mathrm{O} / \mathrm{ZrO}_{2} 60^{\circ} \mathrm{C} ; 12 \mathrm{~h}$ & 42.65 & 38.28 & 8.41 & 10.38 & $1.35 \times 10^{-2}$ & 25.97 \\
\hline${ }^{a}$ Specific surface area & & & & & & \\
${ }^{b}$ Pore diameter & & & & & & \\
${ }^{c}$ Pore volume taken at $\mathrm{P} / \mathrm{P}_{\mathrm{o}}=0.90$ & & & & &
\end{tabular}


in the liquid phase. At temperatures above the boiling point, the methanol is evaporated to reduce the contact interface [46]. Fig. 12 presents the results of FTIR characterization of LGCPO and transesterification compound. According to Pavia et al. [39], C-O vibrations in esters are indicated by strong absorption at 1300 $1000 \mathrm{~cm}^{-1}$, while $\mathrm{C}=\mathrm{O}$ is at $1850-1650 \mathrm{~cm}^{-1}$. This shift is affected by the dipole moment. Oxygen on the ester triggers an increase in frequency in that area. The results of the interpretation of functional groups are summarized in Table 8. The biodiesel content is determined using gas chromatography. The chromatogram of the transesterified compound is presented in Fig. 13. The results of the transesterified compound are listed in Table 9.

Transesterification and LGCPO compounds analyzed by a ${ }^{1} \mathrm{H}$-NMR spectrometer are shown in Fig. 14 and 15 . The results of the analysis are used to confirm the presence of compounds based on the proton environment. An indication that shows the success of transesterification is the appearance of an ester group from triglycerides or FFA.

Based on the results of the LGCPO ${ }^{1} \mathrm{H}-\mathrm{NMR}$ in Fig. 15 , there is a peak that appears in the chemical shift $\delta=$ $4.3 \mathrm{ppm}$ indicating the presence of triglycerides [49]. The characteristic chemical shift of esters compound shows at 2.1 to $2.5 \mathrm{ppm}$ and 3.5 to $4.8 \mathrm{ppm}$ [39]. The presence of peak with triplet integrated at $0.88 \mathrm{ppm}$ indicates the proton of methyl groups. The peak is in the most upfield area, which shows the proton in the least protected environment and is not affected by the induction of other protons.

The methoxy group shows a peak at $3.66 \mathrm{ppm}$ with a singlet pattern. The peak is in a shifting area that is more downfield than the other peaks. The shift is influenced by the pull of electron clouds of carbonyl groups and induction of methoxy groups $\left(-\mathrm{OCH}_{3} \delta=3.66 \mathrm{ppm}\right.$ is 2.59), while triglycerides in LGCPO have integration of 0.66. Methyl ester conversion is calculated from the integration of triglycerides and methyl esters [37]. The

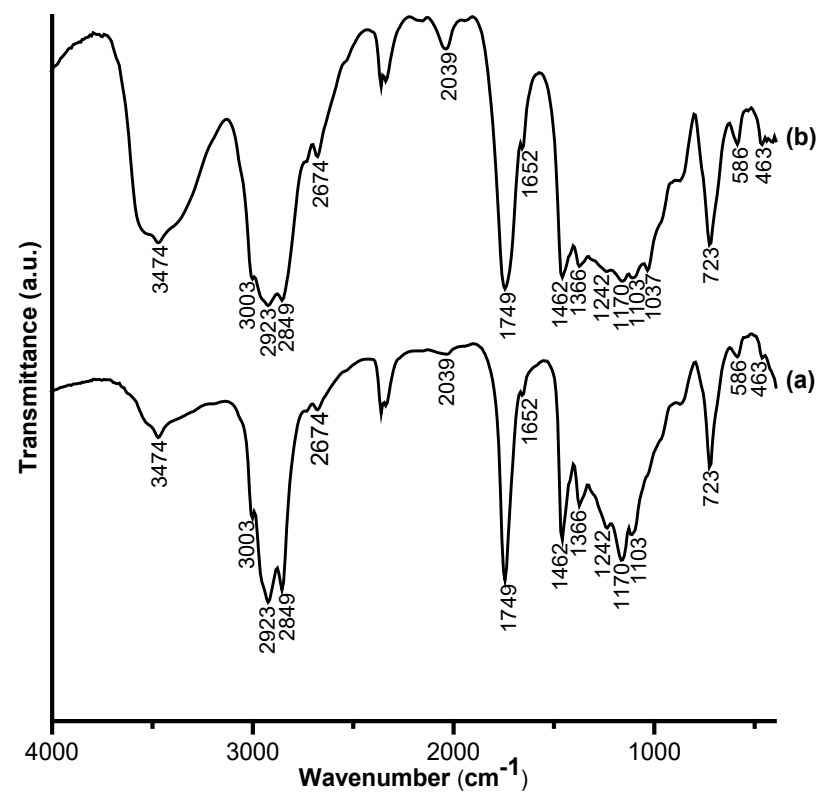

Fig 12. FTIR spectra of (a) LGCPO dan (b) transesterified compound

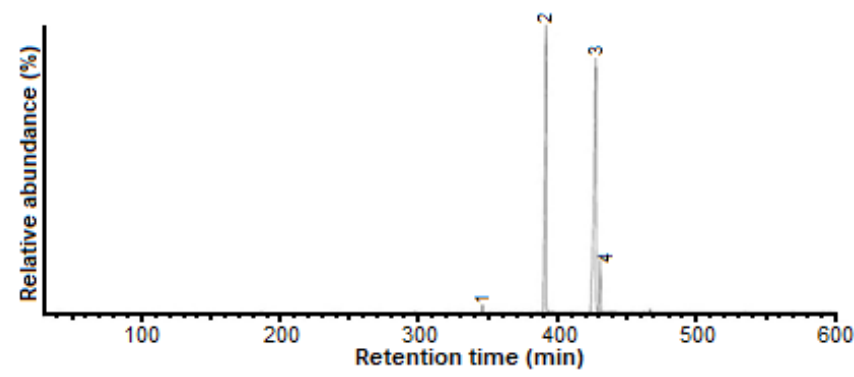

Fig 13. Chromatogram of transesterified compounds

Table 8. Interpretation of FTIR spectra of LGCPO and transesterified compound

\begin{tabular}{llcc}
\hline \multirow{2}{*}{$\begin{array}{l}\text { Functional } \\
\text { group }\end{array}$} & \multirow{2}{*}{ Vibration type } & \multicolumn{2}{c}{ Wavenumber $\left(\mathrm{cm}^{-1}\right)$} \\
\cline { 2 - 4 }$-\mathrm{OH}$ & Stretching & 3474 & 3474 \\
$-\mathrm{CH}_{2}$ & Asymmetry stretching & 2923 & 2923 \\
$-\mathrm{CH}_{2}$ & Symmetry stretching & 2849 & 2849 \\
$-\mathrm{C}=\mathrm{O}$ & Stretching & 1749 & 1749 \\
$-\mathrm{CH}_{2}$ & Shear-type & 1462 & 1462 \\
$-\mathrm{CH}_{3}$ & Bending & 1366 & 1366 \\
$\mathrm{C}-\mathrm{O}-\mathrm{C}$ & Symmetry stretching & 1170 & 1170 \\
$-\mathrm{CH}_{2}$ & Plane rocking & 723 & 723 \\
\hline
\end{tabular}


Table 9. The interpretation of the chromatogram of transesterified compound

\begin{tabular}{cccccc}
\hline Peak & $\begin{array}{c}\text { Retention time } \\
(\mathrm{min})\end{array}$ & Compound & $\begin{array}{c}\text { Molecular } \\
\text { formula }\end{array}$ & $\begin{array}{c}\text { Molecular weight } \\
\left(\mathrm{g} \mathrm{mol}^{-1}\right)\end{array}$ & $\begin{array}{c}\text { Selectivity } \\
(\%)\end{array}$ \\
\hline 1 & 34.6 & Methyl Miristate & $\mathrm{C}_{15} \mathrm{H}_{30} \mathrm{O}_{2}$ & 242 & 0.56 \\
2 & 39.2 & Methyl Palmitate & $\mathrm{C}_{17} \mathrm{H}_{34} \mathrm{O}_{2}$ & 270 & 43.36 \\
3 & 42.7 & Methyl Oleate & $\mathrm{C}_{19} \mathrm{H}_{36} \mathrm{O}_{2}$ & 296 & 51.51 \\
4 & 43.1 & Methyl Stearate & $\mathrm{C}_{19} \mathrm{H}_{38} \mathrm{O}_{2}$ & 298 & 4.57 \\
\hline
\end{tabular}

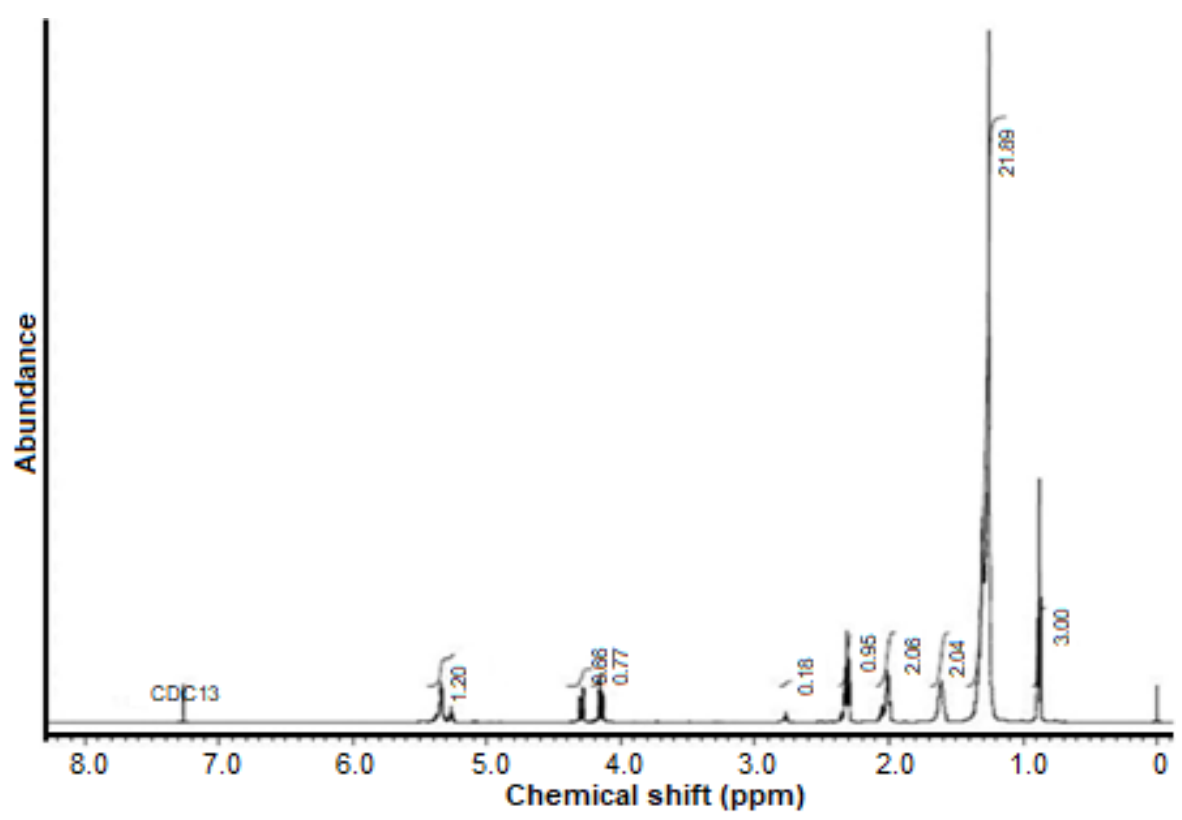

Fig 14. ${ }^{1} \mathrm{H}-\mathrm{NMR}$ spectra of LGCPO

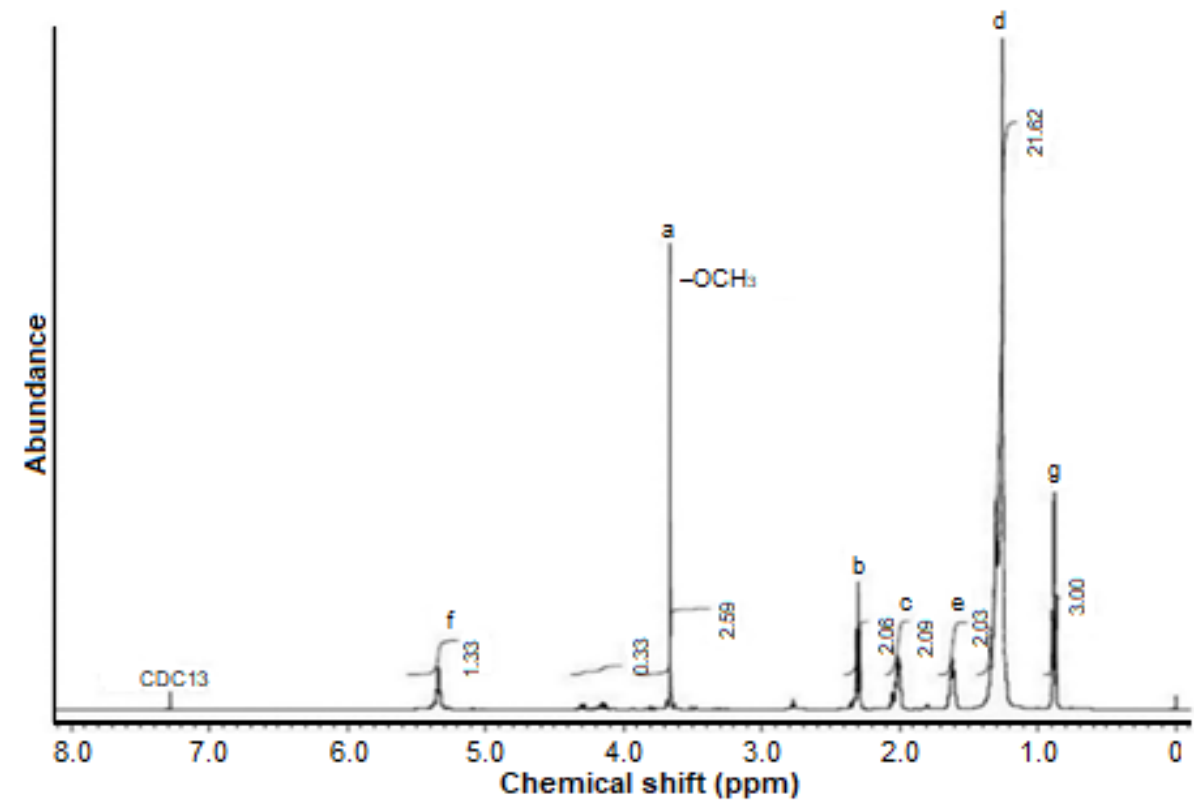

Fig 15. ${ }^{1} \mathrm{H}-\mathrm{NMR}$ spectra of transesterified compound 
Table 10. Calculation of methyl esters conversion

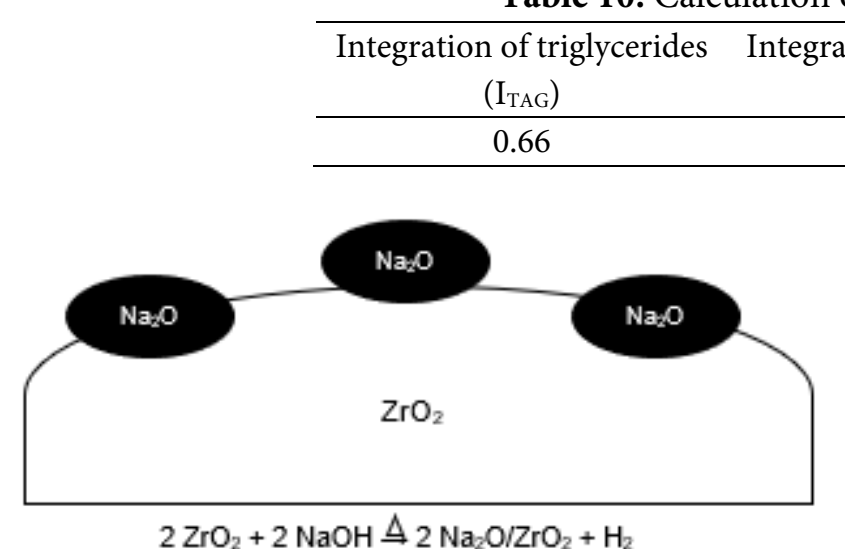

Fig 16. The design of $\mathrm{Na}_{2} \mathrm{O} / \mathrm{ZrO}_{2}$ solid base catalyst formation as a composite material
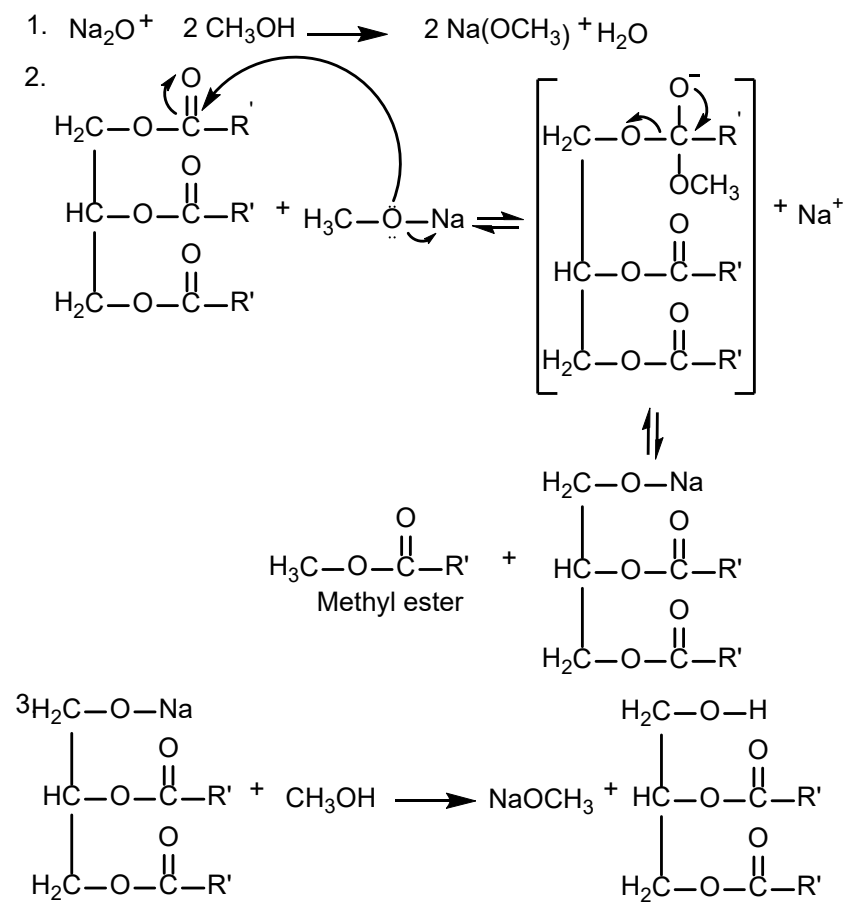

Fig 17. The prediction of the mechanism of transesterification reaction on $\mathrm{Na}_{2} \mathrm{O} / \mathrm{ZrO}_{2}$ solid base catalyst

conversion of methyl ester was $68.55 \%$. After being calculated using the Knotee equation referring to Table 10 , the conversion of methyl ester is $68.55 \%$.

Base catalysts that were synthesized have characteristics as composite materials. The composition design of the composite material of $\mathrm{Na}_{2} \mathrm{O} / \mathrm{ZrO}_{2}$ is illustrated in Fig. 16. Zirconia dioxide has a function as supporting material. The prediction of the mechanism of transesterification reaction on $\mathrm{Na}_{2} \mathrm{O} / \mathrm{ZrO}_{2}$ solid base catalyst is shown in Fig. 17. $\mathrm{Na}_{2} \mathrm{O}$ tends to be in the aqueous phase (methanol) because it is hydrophilic. $\mathrm{Na}_{2} \mathrm{O}$ polarized $\mathrm{CH}_{3} \mathrm{OH}$ to form methoxide ions $\left(-\mathrm{OCH}_{3}\right)$ [50]. Sodium methoxide $\left(\mathrm{NaOCH}_{3}\right)$ is on the surface of $\mathrm{Na}_{2} \mathrm{O} . \mathrm{NaOCH}_{3}$ transfers the methoxy group to carbonyl triglycerides to form insoluble organic salts. The alkoxy triglyceride group binds to sodium to form sodium alkoxy and methyl ester. Alkoxy sodium with excess methanol produces sodium methoxide and glycerol (after all stages have been reached).

\section{- CONCLUSION}

This work demonstrates the synthesis of a solid acid-base catalyst based on $\mathrm{ZrO}_{2}$ for biodiesel conversion. In summary, the design concept of this catalyst synthesis is to maintain a mixture of $\mathrm{ZrO}_{2}$ with $\mathrm{NaOH}$ or $\mathrm{H}_{2} \mathrm{SO}_{4}$ under a certain temperature and pressure. The focus is to understand the influence of several parameters in this reaction system on the catalyst's acidity/basicity properties. The evidence has demonstrated the successful preparation of catalysts. The solid acid catalyst of $\mathrm{SO}_{4}{ }^{2-} / \mathrm{ZrO}_{2} 60^{\circ} \mathrm{C} ; 24 \mathrm{~h}$ had the highest total acidity of $1.86 \mathrm{mmol} \mathrm{g}^{-1}$ using $0.7 \mathrm{M} \mathrm{H}_{2} \mathrm{SO}_{4}$. The solid base catalyst of $\mathrm{Na}_{2} \mathrm{O} / \mathrm{ZrO}_{2} 60^{\circ} \mathrm{C} ; 12 \mathrm{~h}$ has the highest total basicity of $3.75 \pm 0.12 \mathrm{mmol} \mathrm{g}^{-1}$ using $4 \mathrm{M}$ $\mathrm{NaOH}$. The acidity and basicity of the catalyst increase with the increasing concentration of $\mathrm{H}_{2} \mathrm{SO}_{4}$ or $\mathrm{NaOH}$. The total acidity of the $0.7 \mathrm{M} \mathrm{SO}_{4}{ }^{2-} / \mathrm{ZrO}_{2} 60^{\circ} \mathrm{C} ; 24 \mathrm{~h}$ solid acid catalyst and the basicity of $4 \mathrm{M} \mathrm{Na}_{2} \mathrm{O} / \mathrm{ZrO}_{2} 60^{\circ} \mathrm{C}$; $24 \mathrm{~h}$ solid base catalyst decreases with increasing calcination temperature. The release of functional groups on the catalyst causes the acidity and basicity of the catalyst to decrease.

Since we are interested in investigating the performance of these catalysts, some important parameters for biodiesel conversion are conducted. The 
concentration of FFA decreased to $68.87 \%$ after being processed using an optimized acid catalyst. The solid base catalyst of $4 \mathrm{M} \mathrm{Na}_{2} \mathrm{O} / \mathrm{ZrO}_{2} 60{ }^{\circ} \mathrm{C} ; 24 \mathrm{~h}$ successfully converted LGCPO into biodiesel by $68.55 \%$ through a transesterification reaction. The spectroscopic analysis helped to investigate the product. ${ }^{1} \mathrm{H}-\mathrm{NMR}$ revealed the presence of triglycerides $(\delta=4.3 \mathrm{ppm})$ and methoxy groups $(\delta=3.66 \mathrm{ppm})$. The conversion of methyl ester that was obtained is $68.55 \%$. Methyl oleate is the major product, accompanied by other methyl ester compounds, including methyl palmitate, methyl stearate, and a small amount of methyl myristate.

\section{- ACKNOWLEDGMENTS}

The authors are grateful for financial support from the Ministry of Research, Technology and Higher Education of Republic Indonesia through STRANAS Research Grant (contract number 001/SP2H/LT/DRPM/IV/2017) and World Class Research (WCR) 2019 (contract number 1980/UN1.DITLIT/DIT-LIT/LT/2019).

\section{- REFERENCES}

[1] Hajjari, M., Tabatabaei, M., Aghbashlo, M., and Ghanavati, H., 2017, A review on the prospects of sustainable biodiesel production: A global scenario with an emphasis on waste-oil biodiesel utilization, Renewable Sustainable Energy Rev., 72, 445-464.

[2] Muanruksa, P., and Kaewkannetra, P., 2020, Combination of fatty acids extraction and enzymatic esterification for biodiesel production using sludge palm oil as a low-cost substrate, Renewable Energy, 146, 901-906.

[3] Atadashi, I.M., Aroua, M.K., Aziz, A.R.A., and Sulaiman, N.M.N., 2013, The effects of catalysts in biodiesel production: A review, J. Ind. Eng. Chem., 19 (1), 14-26.

[4] Li, Y., Ye, B., Shen, J., Tian, Z., Wang, L., Zhu, L., Ma, T., Yang, D., and Qiu, F., 2013, Optimization of biodiesel production process from soybean oil using the sodium potassium tartrate doped zirconia catalyst under Microwave Chemical Reactor, Bioresour. Technol., 137, 220-225.
[5] Hasanudin, H., Rachmat, A., Said, M., and Wijaya, K., 2020, Kinetic model of crude palm oil hydrocracking over $\mathrm{Ni} / \mathrm{Mo} \mathrm{ZrO}_{2}$-pillared bentonite catalyst, Period. Polytech., Chem. Eng., 64 (2), 238247.

[6] Hayyan, A., Mjalli, F.S., Hashim, M.A., Hayyan, M., AlNashef, I.M., Al-Wahaibi, T., and Al-Wahaibi, Y.M., 2014, A solid organic acid catalyst for the pretreatment of low-grade crude palm oil and biodiesel production, Int. J. Green Energy, 11 (2), 129-140.

[7] Min Oo, Y., Prateepchaikul, G., and Somnuk, K., 2021, Continuous acid-catalyzed esterification using a 3D printed rotor-stator hydrodynamic cavitation reactor reduces free fatty acid content in mixed crude palm oil, Ultrason. Sonochem., 72, 105419.

[8] Pua, F., Fang, Z., Zakaria, S., Guo, F., and Chia, C., 2011, Direct production of biodiesel from high-acid value Jatropha oil with solid acid catalyst derived from lignin, Biotechnol. Biofuels, 4 (1), 56.

[9] Qu, T., Niu, S., Zhang, X., Han, K., and Lu, C., 2021, Preparation of calcium modified $\mathrm{Zn}-\mathrm{Ce} / \mathrm{Al}_{2} \mathrm{O}_{3}$ heterogeneous catalyst for biodiesel production through transesterification of palm oil with methanol optimized by response surface methodology, Fuel, 284, 118986.

[10] Chuah, L.F., Bokhari, A., Yusup, S., Klemeš, J.J., Abdullah, B., and Akbar, M.M., 2016, Optimisation and kinetic studies of acid esterification of high free fatty acid rubber seed oil, Arabian J. Sci. Eng., 41 (7), 2515-2526.

[11] Rattanaphra, D., Harvey, A.P., Thanapimmetha, A., and Srinophakun, P., 2012, Simultaneous transesterification and esterification for biodiesel production with and without a sulfated zirconia catalyst, Fuel, 97, 467-475.

[12] Ropero-Vega, J.L., Aldana-Pérez, A., Gómez, R., and Niño-Gómez, M.E., 2010, Sulfated titania $\left[\mathrm{TiO}_{2} / \mathrm{SO}_{4}{ }^{2-}\right]$ : A very active solid acid catalyst for the esterification of free fatty acids with ethanol, Appl. Catal., A, 379 (1-2), 24-29.

[13] Johnson, M., Ren, J., Lefler, M., Licht, G., Vicini, J., Liu, X., and Licht, S., 2017, Carbon nanotube wools 
made directly from $\mathrm{CO}_{2}$ by molten electrolysis: Value-driven pathways to carbon dioxide greenhouse gas mitigation, Mater. Today Energy, 5, 230-236.

[14] Chouhan, A.P.S., and Sarma, A.K., 2011, Modern heterogeneous catalysts for biodiesel production: A comprehensive review, Renewable Sustainable Energy Rev., 15 (9), 4378-4399.

[15] Devyatkov, S.Y., Zinnurova, A.A., Aho, A., Kronlund, D., Peltonen, J., Kuzichkin, N.V., Lisitsyn, N.V., and Murzin, D.Y., 2016, Shaping of sulfated zirconia catalysts by extrusion: understanding the role of binders, Ind. Eng. Chem. Res., 55 (23), 6595-6606.

[16] Pan, Y., Zhang, J., Xu, Y., Gao, Y., Chen, Z., and Wang, J., 2016, A facile one-pot hydrothermal process to synthesize sulfonated mesoporous $\mathrm{ZrO}_{2}, \mathrm{~J}$. Porous Mater., 23 (2), 489-495.

[17] Utami, M., Trisunaryanti, W., Shida, K., Tsushida, M., Kawakita, H., Ohto, K., Wijaya, K., and Tominaga, M., 2019, Hydrothermal preparation of a platinum-loaded sulfated nanozirconia catalyst for the effective conversion of waste low density polyethylene into gasoline-range hydrocarbons, RSC Adv., 9 (71), 41392-41401.

[18] Li, Y., He, D., Zhu, Q., Zhang, X., and Xu, B., 2004, Effects of redox properties and acid-base properties on isosynthesis over $\mathrm{ZrO}_{2}$-based catalysts, J. Catal., 221 (2), 584-593.

[19] Rabee, A.I.M., Manayil, J.C., Isaacs, M.A., Parlett, C.M.A., Durndell, L.J., Zaki, M.I., Lee, A.F., and Wilson, K., 2018, On the impact of the preparation method on the surface basicity of $\mathrm{Mg}-\mathrm{Zr}$ mixed oxide catalysts for tributyrin transesterification, Catalysts, 8 (6), 228.

[20] Noh, H.J., Seo, D.S., Kim, H., and Lee, J.K., 2003, Synthesis and crystallization of anisotropic shaped $\mathrm{ZrO}_{2}$ nanocrystalline powders by hydrothermal process, Mater. Lett., 57 (16-17), 2425-2431.

[21] Sohn, J.R., Kim, H.W., Park, M.Y., Park, E.H., Kim, J.T., and Park, S.E., 1995, Highly active catalyst of $\mathrm{NiO}-\mathrm{ZrO}_{2}$ modified with $\mathrm{H}_{2} \mathrm{SO}_{4}$ for ethylene dimerization, Appl. Catal., A, 128 (1), 127-141.
[22] Saravanan, K., Tyagi, B., and Bajaj, H.C., 2012, Esterification of caprylic acid with alcohol over nano-crystalline sulfated zirconia, J. Sol-Gel Sci. Technol., 62 (1), 13-17.

[23] Srinivasan, R., Sparks, D.E., and Davis, B.H., 1996, State of platinum in zirconia and sulfated zirconia catalysts, Catal. Lett., 40 (3), 167-173.

[24] Zhang, C., Miranda, R., and Davis, B.H., 1994, Platinum-sulfated-zirconia. Infrared study of adsorbed pyridine, Catal. Lett., 29 (3), 349-359.

[25] Popova, M., Szegedi, Á., Lazarova, H., Dimitrov, M., Kalvachev, Y., Atanasova, G., Ristić, A., Wilde, N., and Gläser, R., 2017, Influence of the preparation method of sulfated zirconia nanoparticles for levulinic acid esterification, React. Kinet., Mech. Catal., 120 (1), 55-67.

[26] Sayılkan, F., Asiltürk, M., Burunkaya, E., and Arpaç, E., 2009, Hydrothermal synthesis and characterization of nanocrystalline $\mathrm{ZrO}_{2}$ and surface modification with 2-acetoacetoxyethyl methacrylate, J. Sol-Gel Sci. Technol., 51 (2), 182-189.

[27] Devulapelli, V.G., and Weng, H.S., 2009, Esterification of 4-methoxyphenylacetic acid with dimethyl carbonate over mesoporous sulfated zirconia, Catal. Commun., 10 (13), 1711-1717.

[28] Qiu, F., Li, Y., Yang, D., Li, X., and Sun, P., 2011, Heterogeneous solid base nanocatalyst: Preparation, characterization and application in biodiesel production, Bioresour. Technol., 102 (5), 4150-4156.

[29] El-Desouki, D.S., Ibrahim, A.H., Abdelazim, S.M., Aboul-Gheit, N.A.K., and Abdel-Hafizar, D.R., 2021, The optimum conditions for methanol conversion to dimethyl ether over modified sulfated zirconia catalysts prepared by different methods, $J$. Fuel Chem. Technol., 49 (1), 63-71.

[30] Pratap, S.R., Shamshuddin, S.Z.M., and Shyamprasad, K., 2020, Microwave assisted synthesis of propyl esters over modified versions of zirconia: Kinetic study, Chem. Data Collect., 30, 100579.

[31] Essamlali, Y., Amadine, O., Larzek, M., Len, C., and Zahouily, M., 2017, Sodium modified hydroxyapatite: Highly efficient and stable solid- 
base catalyst for biodiesel production, Energy Convers. Manage., 149, 355-367.

[32] Abedin, M.A., Kanitkar, S., Bhattar, S., and Spivey, J.J., 2021, Methane dehydroaromatization using Mo supported on sulfated zirconia catalyst: Effect of promoters, Catal. Today, 365, 71-79.

[33] Marinković, D.M., Stanković, M.V., Veličković, A.V., Avramović, J.M., Miladinović, M.R., Stamenković, O.O., Veljković, V.B., and Jovanović, D.M., 2016, Calcium oxide as a promising heterogeneous catalyst for biodiesel production: Current state and perspectives, Renewable Sustainable Energy Rev., 56, 1387-1408.

[34] Helmiyati, H., Budiman, Y., Abbas, G.H., Dini, F.W., and Khalil, M., 2021, Highly efficient synthesis of biodiesel catalyzed by a cellulose@hematite-zirconia nanocomposite, Heliyon, 7 (3), e06622.

[35] dos Santos, L.K., Hatanaka, R.R., de Oliveira, J.E., and Flumignan, D.L., 2019, Production of biodiesel from crude palm oil by a sequential hydrolysis/esterification process using subcritical water, Renewable Energy, 130, 633-640.

[36] Chong, Y.Y., Thangalazhy-Gopakumar, S., Gan, S., Lee, L.Y., and Ng, H.K., 2020, Esterification and neutralization of bio-oil from palm empty fruit bunch fibre with calcium oxide, Bioresour. Technol. Rep., 12, 100560.

[37] Knothe, G., 2000, Monitoring a progressing transesterification reaction by fiber-optic near infrared spectroscopy with correlation to ${ }^{1} \mathrm{H}$ nuclear magnetic resonance spectroscopy, J. Am. Oil Chem. Soc., 77 (5), 489-493.

[38] Shi, G., Yu, F., Wang, Y., Pan, D., Wang, H., and Li, R., 2016, A novel one-pot synthesis of tetragonal sulfated zirconia catalyst with high activity for biodiesel production from the transesterification of soybean oil, Renewable Energy, 92, 22-29.

[39] Pavia, D.L., Lampman, G.M., Kriz, G.S., and Vyvyan, J.A., 2009, Introduction to Spectroscopy, $4^{\text {th }}$ Ed., Brooks/Cole, Cengage Learning, Belmont, CA.

[40] Liu, N., Ma, Z., Wang, S., Shi, L., Hu, X., and Meng, X., 2020, Palladium-doped sulfated zirconia:
Deactivation behavior in isomerization of $n$ hexane, Fuel, 262, 116566.

[41] Navio, J.A., Colón, G., Sánchez-Soto, P.J., and Macias, M., 1997, Effects of $\mathrm{H}_{2} \mathrm{O}_{2}$ and $\mathrm{SO}_{4}{ }^{2-}$ species on the crystalline structure and surface properties of $\mathrm{ZrO}_{2}$ processed by alkaline precipitation, Chem. Mater., 9 (5), 1256-1261.

[42] Tuong, T., Tran, V., Kaiprommarat, S., Kongparakul, S., Reubroycharoen, P., Guan, G., Huan, M., and Samart, C., 2016, Green biodiesel production from waste cooking oil using an environmentally benign acid catalyst, Waste Manage., 52, 367-374.

[43] El-Dafrawy, S.M., Hassan, S.M., and Farag, M., 2020, Kinetics and mechanism of Pechmann condensation reaction over sulphated zirconia-supported zinc oxide, J. Mater. Res. Technol., 9 (1), 13-21.

[44] Vannucci, J.A., Nichio, N.N., and Pompeo, F., 2021, Solketal synthesis from ketalization of glycerol with acetone: A kinetic study over a sulfated zirconia catalyst, Catal. Today, 372, 238-245.

[45] Pirez, C., Reche, M.T., Lee, A.F., Manayil, J.C., dosSantos, V.C., and Wilson, K., 2015, Hydrothermal saline promoted grafting of periodic mesoporous organic sulfonic acid silicas for sustainable FAME production, Catal. Lett., 145 (7), 1483-1490.

[46] Colombo, K., Ender, L., and Barros, A.A.C., 2017, The study of biodiesel production using $\mathrm{CaO}$ as a heterogeneous catalytic reaction, Egypt. J. Pet., 26 (2), 341-349.

[47] Zhang, H., Luo, X., Shi, K., Wu, T., He, F., Yang, H., Zhang, S., and Peng, C., 2019, Nanocarbon-based catalysts for esterification: Effect of carbon dimensionality and synergistic effect of the surface functional groups, Carbon, 147, 134-145.

[48] Chang, A., Pan, J.H., Lai, N.C., Tsai, M.C., Mochizuki, T., Toba, M., Chen, S.Y., and Yang, C.M., 2020, Efficient simultaneous esterification/transesterification of non-edible Jatropha oil for biodiesel fuel production by template-free synthesized nanoporous titanosilicates, Catal. Today, 356, 56-63. 
[49] Shah, K.A., Parikh, J.K., and Maheria, K.C., 2014, Optimization studies and chemical kinetics of silica sulfuric acid-catalyzed biodiesel synthesis from waste cooking oil, Bioenergy Res., 7 (1), 206-216.
[50] Saravana Sathiya Prabhahar, R., Benitha, V.S., and Nagarajan, J., 2021, Improved yield of palm oil biodiesel through nano catalytic transesterification, Mater. Today: Proc., 46, 8433-8437. 